\title{
Enhancing Omega-3 Long-Chain Polyunsaturated Fatty Acid Content of Dairy-Derived Foods for Human Consumption
}

\author{
Quang V. Nguyen ${ }^{1,2}{ }^{\oplus}$, Bunmi S. Malau-Aduli ${ }^{3}$, John Cavalieri ${ }^{1}{ }^{(\mathbb{C}}$, Peter D. Nichols ${ }^{1,4,5,6}$ \\ and Aduli E. O. Malau-Aduli 1,7,*(D) \\ 1 Animal Genetics and Nutrition, Veterinary Sciences Discipline, College of Public Health, \\ Medical and Veterinary Sciences, Division of Tropical Health and Medicine, James Cook University, \\ Townsville, QLD 4811, Australia; quang.nguyen2@my.jcu.edu.au (Q.V.N.); john.cavalieri@jcu.edu.au (J.C.); \\ Peter.Nichols@csiro.au (P.D.N.) \\ 2 College of Economics and Techniques, Thai Nguyen University, Thai Nguyen 252166, Vietnam \\ 3 College of Medicine and Dentistry, Division of Tropical Health and Medicine, James Cook University, \\ Townsville, QLD 4811, Australia; bunmi.malauaduli@jcu.edu.au \\ 4 CSIRO Oceans \& Atmosphere, P.O. Box 1538, Hobart, TAS 7001, Australia \\ 5 Nutrition Society of Australia (NSA), Level 3, 33-35 Atchison Street, St Leonards, NSW 2065, Australia \\ 6 Australasian Section, American Oil Chemists Society (AAOCS), 2710 S. Boulder, Urbana, IL 61802-6996, USA \\ 7 Asia Pacific Nutrigenomics and Nutrigenetics Organisation (APNNO), CSIRO Food \& Nutrition, \\ Adelaide, SA 5000, Australia \\ * Correspondence: aduli.malauaduli@jcu.edu.au; Tel.: +61-7-4781-5339
}

Received: 24 February 2019; Accepted: 27 March 2019; Published: 29 March 2019

\begin{abstract}
Omega-3 polyunsaturated fatty acids (n-3 PUFA) are termed essential fatty acids because they cannot be synthesized de novo by humans due to the lack of delta-12 and delta-15 desaturase enzymes and must therefore be acquired from the diet. n-3 PUFA include $\alpha$-linolenic acid (ALA, 18:3n-3), eicosapentaenoic (EPA, 20:5n-3), docosahexaenoic (DHA, 22:6n-3), and the less recognized docosapentaenoic acid (DPA, 22:5n-3). The three long-chain $\left(\geq C_{20}\right) n-3$ PUFA (n-3 LC-PUFA), EPA, DHA, and DPA play an important role in human health by reducing the risk of chronic diseases. Up to the present time, seafood, and in particular, fish oil-derived products, have been the richest sources of n-3 LC-PUFA. The human diet generally contains insufficient amounts of these essential FA due largely to the low consumption of seafood. This issue provides opportunities to enrich the content of n-3 PUFA in other common food groups. Milk and milk products have traditionally been a major component of human diets, but are also among some of the poorest sources of n-3 PUFA. Consideration of the high consumption of milk and its processed products worldwide and the human health benefits has led to a large number of studies targeting the enhancement of n-3 PUFA content in dairy products. The main objective of this review was to evaluate the major strategies that have been employed to enhance n-3 PUFA content in dairy products and to unravel potential knowledge gaps for further research on this topic. Nutritional manipulation to date has been the main approach for altering milk fatty acids (FA) in ruminants. However, the main challenge is ruminal biohydrogenation in which dietary PUFA are hydrogenated into monounsaturated FA and/or ultimately, saturated FA, due to rumen microbial activities. The inclusion of oil seed and vegetable oil in dairy animal diets significantly elevates ALA content, while the addition of rumen-protected marine-derived supplements is the most effective way to increase the concentration of EPA, DHA, and DPA in dairy products. In our view, the mechanisms of n-3 LC-PUFA biosynthesis pathway from ALA and the biohydrogenation of individual n-3 LC-PUFA in ruminants need to be better elucidated. Identified knowledge gaps regarding the activities of candidate genes regulating the concentrations of n-3 PUFA and the responses of ruminants to specific lipid supplementation regimes are also critical to a greater understanding of nutrition-genetics interactions driving lipid metabolism.
\end{abstract}


Keywords: dairy-derived foods; n-3 LC-PUFA; milk; cheese; lipids; oil; nutritional supplementation; genetic manipulation; candidate genes; FADS

\section{Introduction}

Omega-3 polyunsaturated fatty acids (n-3 PUFA) contain more than two double bonds with the first double bond on the third carbon atom from the methyl end of the molecule. The common types of $n-3$ PUFA are: Shorter chain (SC, $\leq \mathrm{C}_{18}$ ) n-3 PUFA including $\alpha$-linolenic acid (ALA, 18:3n-3) and stearidonic acid (SDA, 18:4n-3), and long-chain ( $\left.\geq C_{20}\right)$ n-3 PUFA (n-3 LC-PUFA) including eicosapentaenoic (EPA, 20:5n-3); docosahexaenoic (DHA, 22:6n-3); and the less studied docosapentaenoic (DPA, 22:5n-3) acids [1]. The focus herein is on LC-PUFA due to their beneficial effects in human pathologies. Since Bang et al. [2] first demonstrated the positive relationship between low amounts of some non-communicable diseases and high n-3 LC-PUFA consumption of the Eskimos, numerous studies have consistently demonstrated their vital role in inhibiting major chronic diseases [3], including adipogenic, diabetogenic, atherogenic [4], inflammatory [5,6] and carcinogenic [7,8] diseases. Moreover, high consumption of n-3 LC-PUFA is typically associated with a higher cognitive performance and a lower risk of developing Alzheimer's disease [9-11]. Previous studies on n-3 LC-PUFA have focused mainly on EPA and DHA, but not DPA despite its structural and beneficial effects on human health being similar to those of EPA and DHA [12]. The unavailability of pure DPA as a commercial product for performing clinical and nutritional trials is one possible explanation for this shortcoming. The term n-3 LC-PUFA in this current review includes EPA, DHA, and DPA.

Chronic or non-communicable diseases have remained as the most leading cause of death worldwide, with 41 million deaths accounting for $71 \%$ of reported global deaths (57 million) [13]. This report also indicated that an unhealthy diet with low intake of n-3 LC-PUFA, continues to be one of the main factors that either directly or indirectly induce chronic diseases. Although there is a general awareness that fish and seafood are the dominant source of n-3 LC-PUFA, seafood consumption is still insufficient, thus the human diet persists with low n-3 PUFA intake [14]. The traditional diet often does not contain regular consumption of fish and marine products, especially in Western countries [12,15]. When taken together with the often high cost of seafood [16], these combined factors probably have been the major grounds for this trend. In contrast, milk and its processed products are known as poor sources of n-3 LC-PUFA content [17], although they have played an important role in human diets for more than 8000 years [18]. This is because dairy foods are important sources of energy, protein, fat, and vital microelements including calcium, vitamin D and potassium for humans [19,20]. According to the OECD/FAO report [21], the 2015 global consumption of milk and dairy products was $111.3 \mathrm{~kg}$ per capita, and is expected to increase by approximately $12.5 \%$ by 2025 . This fact has led to a number of studies focusing on enhancing the beneficial n-3 PUFA and n-3 LC-PUFA in milk and its processed products, mostly from cows and sheep, for human consumption [17]. The aim of the present review was, therefore, to evaluate and update the published literature on the effects of n-3 LC-PUFA on human health and to also examine recent research on improving the concentrations of these health beneficial FA in dairy-derived foods. Consequently, outcomes from this review may open up opportunities for future further research into nutrition-genetics interactions influencing lipid metabolism in dairy-derived foods.

\section{Metabolic Pathways, Human Health Benefits and Recommended Intake of n-3 PUFA}

\subsection{Dietary n-3 PUFA Intake Recommendations}

Dietary intake recommendations of n-3 LC-PUFA from different organizations vary largely and also depend on many factors including age, gender, and consumption purposes of consumers [1,22]. Adhering to National Health and Medical Research Council (NHMRC) recommendations [23], the daily 
intakes of ALA and total EPA+DPA+DHA considered adequate for men are $1.3 \mathrm{~g} / \mathrm{day}$, and $160 \mathrm{mg} / \mathrm{day}$, and for women, $0.8 \mathrm{~g} /$ day and $90 \mathrm{mg} /$ day, respectively. These dietary requirements of n-3 PUFA are not optimal, but are seen as sufficient to prevent deficiency symptoms for adults. However, with the aim at reducing chronic disease risk, the NHMRC suggested that dietary intakes of total n-3 LC-PUFA of $430 \mathrm{mg} /$ day for women, and $610 \mathrm{mg} /$ day for men should be adequate to meet requirement levels. In order to prevent the risk of coronary heart disease, FAO and WHO [24] recommended sufficient daily intake of EPA + DHA at $250 \mathrm{mg}$ for adult males and non-pregnant or/and non-lactating adult females, and at $300 \mathrm{mg}$ for lactating and pregnant women. In the case of disease treatment, such as for hypertriglyceridemia patients who have high triglyceride level symptoms, a much higher intake of total EPA + DHA from 2-4 g/day is recommended by the American Heart Association [25]. A recent review by Nguyen et al. [22] stated that the intake recommendation of n-3 LC-PUFA for primary prevention of cardiovascular disease across all organizations is about $500 \mathrm{mg} /$ day, which is equivalent to two or three servings of fish per week.

\subsection{Metabolic Pathways for the Biosynthesis and Dietary Sources of n-3 PUFA}

Due to the lack of delta-12 and delta-15 desaturase enzymes, mammals (including humans) cannot synthesize n-3 PUFA de novo, thus these essential FA must be acquired via foods or nutritional supplements [26]. The first step in the n-3 LC-PUFA synthesis pathway for the human body is the conversion of ALA to SDA, with ALA mostly acquired from green plant tissues and plant-derived oils, especially flaxseed/linseed and canola oil [27] (Table 1).

Table 1. Common food sources of ALA (18:3n-3, as gram per serving).

\begin{tabular}{ccc}
\hline Item & Unit & ALA \\
\hline Flaxseed oil & g/tbsp & 7.26 \\
Chia seed & g/ounce & 5.06 \\
English walnuts & g/ounce & 2.57 \\
Whole flaxseed & g/tbsp & 2.35 \\
Canola oil & g/tbsp & 1.28 \\
Soybean oil & g/tbsp & 0.92 \\
Black walnut & g/ounce & 0.76 \\
\hline
\end{tabular}

Data from Office of Dietary Supplements, National Institute of Health (NIH) [28]. Tbsp denotes tablespoon.

There are two recognised biosynthesis pathways for n-3 LC-PUFA (Figure 1), including the presently accepted pathway [29] and conventional metabolic pathway [30]. In the former pathway, DHA was produced from DPA via sequential desaturation and elongation combined with a final $\beta$-oxidation where tetracosapentaenoic acid (24:5n-3) is chain-shortened by two carbons. The latter conventional metabolic pathway, in contrast, consists of direct conversion of DHA from DPA under the catalysis of delta-4 desaturase enzyme. The molecular evidence for delta-4 desaturase that supported the conventional metabolic pathway for n-3 LC-PUFA biosynthesis was first demonstrated by Park et al. [31]. Further research is needed to clarify the specific pathway for n-3 LC-PUFA biosynthesis in the human body, but most studies have confirmed a very low rate of conversion of ALA to n-3 LC-PUFA, in particular, to DHA ( $0.05 \%$ or less) [32]. The specific mechanism(s) by which biosynthesis of these essential FA occurs is limited in man and is still largely unknown. Calder [3] suggested that a possible cause for this limitation is the competition between biosynthetic pathways of ALA conversion to n-3 LC-PUFA and linoleic acid (18:2n-6) conversion to n-6 LC-PUFA as the two pathways employ the same set of enzymes. In addition, based on previous animal studies, deficiencies of insulin [33], protein [34] and microminerals [35] might lead to lower delta-6 desaturase enzyme activity, thus contributing to the low efficiency of this pathway. 
$\alpha$-Linolenic acid (ALA, 18:3n-3)

$\Delta 6$-desaturase

Stearidonic acid (SDA, 18:4n-3)

Elongase

Eicosatetraenoic acid (ETA, 20:4n-3)

$\Delta$ 5-desaturase

Eicosapentaenoic acid (EPA, 20:5n-3)

Elongase

Elongase

Docosapentaenoic acid (n-3 DPA, 22:5n-3)

$\Delta 4$-desaturase
$\Delta 6$-desaturase

Tetracosapentaenoic acid (24:5n-3)

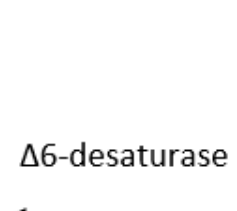

Docosahexaenoic acid (DHA, 22:6n-3) $\leftarrow------\quad$ Tetracosahexaenoic acid (24:6n-3)

Figure 1. Possible biosynthesis and metabolic pathway of n-3 LC-PUFA. Thick arrows represent the conventional pathway; dotted lines with arrows represent presently accepted pathway (adapted from Park et al. [30] and Sprecher [29]).

Due to the limitation of n-3 LC-PUFA biosynthesis in the human body from ALA, the best way of acquiring these essential FA is from dietary sources [36]. Fish and seafood currently are the major sources of n-3 LC-PUFA with high concentration ranges across seafood species $[1,37]$. The average content of total n-3 LC-PUFA in $150 \mathrm{~g}$ wet weight of wild caught Australian fish, shellfish, prawns, and lobsters are 350, 250,180, and $160 \mathrm{mg}$ respectively, with a range of species also having markedly higher contents than these average values [1]. The level of these FA for the two common fish species farmed in Australia - Atlantic salmon, and barramundi - examined by Nichols et al. [38] are 980 and $790 \mathrm{mg} / 100 \mathrm{~g}$, respectively. Compared to the previous results [1], the concentration of n-3 LC-PUFA for these farmed fish had decreased significantly by $50 \%$ or more. Changes in feed ingredients for farmed fish, in which fish meal and fish oils have been substituted by non-traditional oil sources such as plant and/or chicken oils were the reasons for this trend [38]. Foods derived from animals have much lower n-3 LC-PUFA content in comparison to marine products (Table 2). 
Table 2. Content of n-3 LC-PUFA in common seafood and other animal sources.

\begin{tabular}{|c|c|c|c|c|c|c|}
\hline Item & Unit & EPA & DHA & DPA & Total n-3 LC-PUFA & Reference \\
\hline Wild seafood & & & & & & Nichols et al. [1] \\
\hline Fish & $\mathrm{mg} / 150 \mathrm{~g}$ & - & - & - & 350 & \\
\hline Shellfish & $\mathrm{mg} / 150 \mathrm{~g}$ & - & - & - & 225 & \\
\hline Prawns & $\mathrm{mg} / 150 \mathrm{~g}$ & - & - & - & 180 & \\
\hline Lobster & $\mathrm{mg} / 150 \mathrm{~g}$ & - & - & - & 160 & \\
\hline \multicolumn{7}{|l|}{ Farmed fish } \\
\hline Atlantic salmon & $\mathrm{mg} / 100 \mathrm{~g}$ & - & - & - & 980 & Nichols et al. [38] \\
\hline Barramundi & $\mathrm{mg} / 100 \mathrm{~g}$ & - & - & - & 790 & \\
\hline \multicolumn{7}{|l|}{ Other animal sources } \\
\hline Beef & $\mathrm{mg} / 100 \mathrm{~g}$ & 15 & 12 & 20 & 47 & Garcia et al. [39] \\
\hline Chicken breast & $\mathrm{mg} / 100 \mathrm{~g}$ & - & - & - & 62.04 & Konieczka et al. [40] \\
\hline Pork & $\mathrm{mg} / 100 \mathrm{~g}$ & 23.3 & 3.9 & 21.1 & 48.3 & Dugan et al. [41] \\
\hline \multirow[t]{2}{*}{ Feedlot lamb meat } & $\mathrm{mg} / 100 \mathrm{~g}$ & 17.9 & 4.9 & 15.6 & 38.4 & Nguyen et al. [42] \\
\hline & & 28.9 & 13.3 & 19.6 & 61.8 & Le et al. [43] \\
\hline Grazing lamb meat & $\mathrm{mg} / 100 \mathrm{~g}$ & 25 & 7.1 & 23.7 & 55.8 & Le et al. [44] \\
\hline Sheep milk & $\mathrm{mg} / 250 \mathrm{~mL}$ & 17.8 & 19.8 & 24.1 & 61.7 & Nguyen et al. [45] \\
\hline Sheep cheese & $\mathrm{mg} / 40 \mathrm{~g}$ & 14.3 & 12.8 & 17.1 & 44.2 & Nguyen et al. [46] \\
\hline Cow milk & $\mathrm{mg} / 100 \mathrm{~g}$ & 3.3 & - & 4.4 & - & Benbrook et al. [47] \\
\hline
\end{tabular}

\section{3. n-3 LC-PUFA Consumption and Chronic Diseases}

The biological functions of n-3 LC-PUFA are firstly represented by their occurrence in all cellular membranes in all tissues of the body, and in particular, at high content levels in the retina, brain, and myocardium $[48,49]$. For example, due to a high concentration of DHA in the membranes of the human retina and brain, it plays an important role in regulating membrane receptors, membrane-bound enzymes and transduction signals [48]. In addition, n-3 LC-PUFA have the potential to transform into a group of mediators such as the E-series and D-series resolvins at the expense of inflammation mediators from arachidonic acid (20:4n-6, ARA) which is the primary cause of various chronic disease treatments [49,50]. Chronic inflammation that persists for a long time has a strong link with the development of many chronic diseases including cancer, cardiovascular (CVD), neurodegenerative, and respiratory diseases [3,51]. Moreover, there is a positive correlation between n-3 PUFA dietary consumption and incorporation of these FA into cell membranes [52,53] that explains a positive effect of adequate dietary n-3 PUFA consumption on inhibiting chronic diseases.

Cardiovascular diseases refer to a collective term for heart and/or blood vessels related diseases that are by far, the most leading cause of mortality worldwide with 17.9 million deaths reported in 2018 [13]. Therefore, the effects of n-3 PUFA on major CVD including coronary heart disease (CHD) and stroke have been reported in numerous studies [54-56]. One of the potential roles of n-3 PUFA in reducing the risk of CHD is by counteracting many steps of atherosclerosis [57], the major cause of CHD [58]. Novel findings [59] demonstrated that enriched-DHA canola oil supplementation could reduce the risk of CHD by improving high-density lipoprotein cholesterol, triglycerides, and blood pressure. In addition, previous meta-analyses established the link between increasing intakes of n-3 LC-PUFA and reducing the risk of CHD death by 10-30\% [54]. In terms of stroke, dietary consumption of n-3 PUFA can reduce the volume of ischemic stroke [60] by promoting antioxidant enzyme activities or partly acting as an antioxidant. n-3 PUFA can provide further benefits relating to stroke post-treatments [55], by generating other important responses such as neuranagenesis and revascularization. The latest meta-analysis of prospective cohort studies [61] supported a strong inverse relationship between daily fish intake and the risk of stroke. Following CVD, cancer is the second most common cause of death [13]. Clinical and epidemiological studies have demonstrated the role of n-3 LC-PUFA in either reducing the risk of developing cancer or improving chemotherapy outcomes in existing cancer patients of several common types of cancer [3,62]. Long-term studies by Kato et al. [63], Terry et al. [64] and Takezaki et al. [65] concluded that increased consumption of dietary n-3 LC-PUFA lowered the risk 
of colorectal, prostate and lung cancer, respectively. Van Blarigan et al. [66] also reported that higher intake of n-3 LC-PUFA improved disease-free survival by $28 \%$ in colon cancer patients. The effect of these PUFA is more varied. While Holmes et al. [56] showed no relation between fish consumption and breast cancer, recent studies confirmed the positive impact of n-3 fat on not only inhibiting $[67,68]$, but also reducing fatigue [69], in breast cancer patients. In contrast to the large number of studies that confirmed the positive effects of n-3 PUFA on these two major chronic diseases, other research findings reported neutral, inconclusive or even possible negative effects [62]. For instance, there was no statistically significant association between major CVD events and n-3 PUFA supplementation based on a meta-analysis of previous randomized clinical trials [70]. Similarly, results from a large prospective cohort study by Rhee et al. [71] reported a neutral effect of n-3 PUFA intake on the risk of major CVD in healthy women aged $\geq 45$ years. With respect to cancer, Holmes et al. [72] showed that there was no relationship between fish consumption and breast cancer, while in one case, the intake of n-3 PUFA was claimed to induce the risk of basal cell carcinoma on skin cancer [73].

Apart from CVD and cancer, large studies have recognised the role of n-3 LC-PUFA in regards to brain related cognitive treatments and other common chronic diseases such as rheumatoid arthritis, type-2 diabetes and obesity. Relating to brain issues in humans, bioactivities of n-3 LC-PUFA, particularly DHA, play an important role in neural membrane structure, neurotransmission, and signal transduction [74], and positive effects on treatment of different neurodegenerative and neurological disorders [75]. Lower n-3 PUFA intakes have been reported to induce the risk of Alzheimer's disease [76], while increased fish oil intakes for Parkinson's disease patients resulted in a significant reduction in depressive symptoms [77]. Examining rheumatoid arthritis, Abdulrazaq et al. [78] reported that a majority of studies confirmed the beneficial effect of utilising n-3 LC-PUFA at doses of 3-6 g/day on pain relief in patients. Findings on the benefits of n-3 PUFA consumption in type-2 diabetes and obesity remain inconsistent. While some authors have recognised that $n-3$ PUFA intake can reduce the incidence of diabetes $[79,80]$, the findings from a systematic review and meta-analysis reported by Wu et al. [81] suggested a neutral effect of EPA + DHA and seafood consumption on the development of diabetes. Similarly, no significant relationship between n-3 PUFA and obesity was reported in the review by Albracht-Schulte et al. [82]. In contrast, high fish intake in men could lower the risk of being overweight [83], although an opposite result was observed in women with higher fish consumption [84].

The controversies regarding the role of n-3 PUFA in chronic diseases may be explained by many factors such as dose, duration, baseline intake [85], specific type of the chronic disease and risk group [86]. Due to this continuous debate and variations in experimental design, it has not been very evident from current scientific literature and medical opinion confirming or rejecting the beneficial effects of n-3 PUFA in reducing the risk of human chronic diseases [62]. Therefore, large and unified clinical trials need to be conducted to conclusively identify the exact role of n-3 PUFA as independent or supplementary factors in specific chronic diseases.

\section{Lipid Metabolism in Ruminants: Obstacles to Enriching Milk Fat with n-3 PUFA}

Since all of the long-chain FA in milk fat are derived from the absorption of fatty acids from the small intestine and body fat reserves that have both originated from dietary FA $[17,87]$, manipulating the diet or feeding regime is the most popular way to alter milk fat composition. However, the efficiency of this approach in ruminants is still limited due to rumen microbial fermentation [88].

Dietary lipid sources for ruminants are mainly from forages, supplements or concentrates including cereal grains, oilseeds and animal fats. Lipids derived from forages contain largely glycolipids and phospholipids, while triglycerides are found primarily in supplements [89]. Once dietary lipids enter the rumen, lipolysis occurs and it involves hydrolysis of ester linkages to release free fatty acids for the next biohydrogenation (BH) process [88] (Figure 2). 


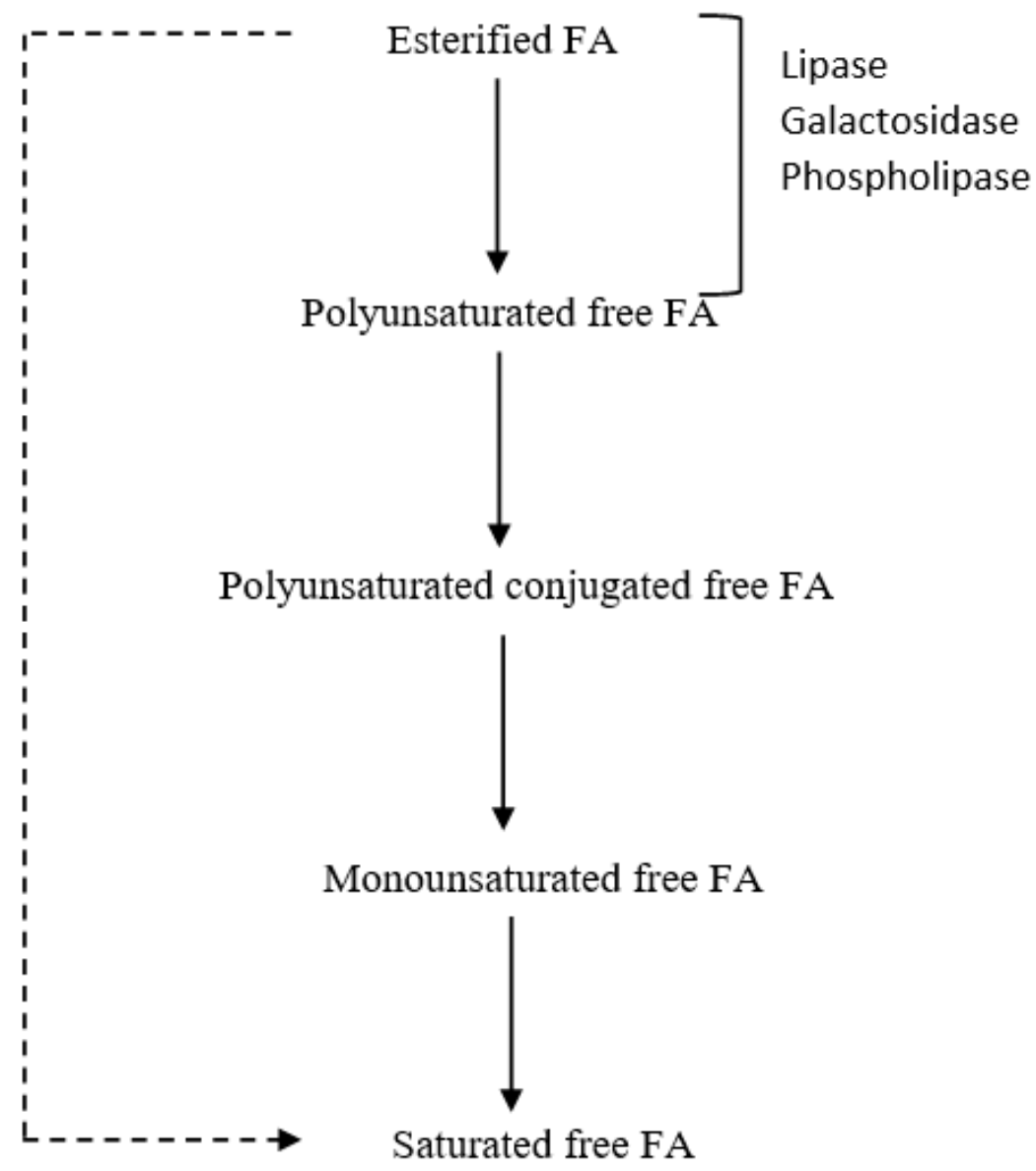

Figure 2. The scheme of lipolysis and biohydrogenation (adapted from Buccioni et al. [88]).

Under the activity of rumen microbes, unsaturated fatty acids (UFA) including PUFA are hydrogenated to monounsaturated FA (MUFA) and ultimately, saturated FA (SFA) through the addition of a double bond of two hydrogen atoms. The principal role of this process is to maintain a stable rumen environment by reducing the toxic effects of free UFA on bacterial growth in the rumen [89]. Due to the high rate of hydrolysis and $\mathrm{BH}$, only small amounts of PUFA from the diet can pass through the rumen into the duodenum for absorption [90]. According to Shingfield et al. [91], dietary ALA in the rumen can be hydrogenated into 18:0 (Figure 4) at the rate of $85 \%$ to $100 \%$. Both in vivo [92] and in vitro [93] studies have confirmed an extensive BH of dietary EPA and DHA that was greater than $90 \%$. In contrast to ALA, these PUFA are not completely hydrogenated into SFA, but numerous intermediates are produced including a majority of UFA and much lesser amounts of SFA [94]. The most recent in vitro study [95] suggests that while the reduction of the double bond at the closest position to the carboxyl group is the main BH pathway of EPA and DPA (Figure 3), this process is much less important for DHA. In addition, these authors stated that the possible interspecies differences between bovine and ovine BH of n-3 LC-PUFA is directly correlated with slower and less complete BH observed in cattle, especially for EPA and DPA. However, the specific pathways for $\mathrm{BH}$ of individual n-3 LC-PUFA still remain unclear.

Apart from ruminal $\mathrm{BH}$, given the relatively low absorption rate from the small intestine into the mammary gland at $49 \%$ for ALA, and ranging from $14 \%$ to $33 \%$ for $\mathrm{EPA}$, and from $13 \%$ to $25 \%$ for DHA [17], it is not surprising that the proportion of these PUFA in dairy products is generally very low. Principal strategies for increasing n-3 PUFA in milk and milk products, therefore, have been to minimize the biohydrogenation effects of ruminal microbes and/or improving the absorption rate of these FA into the mammary gland. 
cis- - , cis- 8 , cis- 11 , cis- 14 , cis- 17 20:5

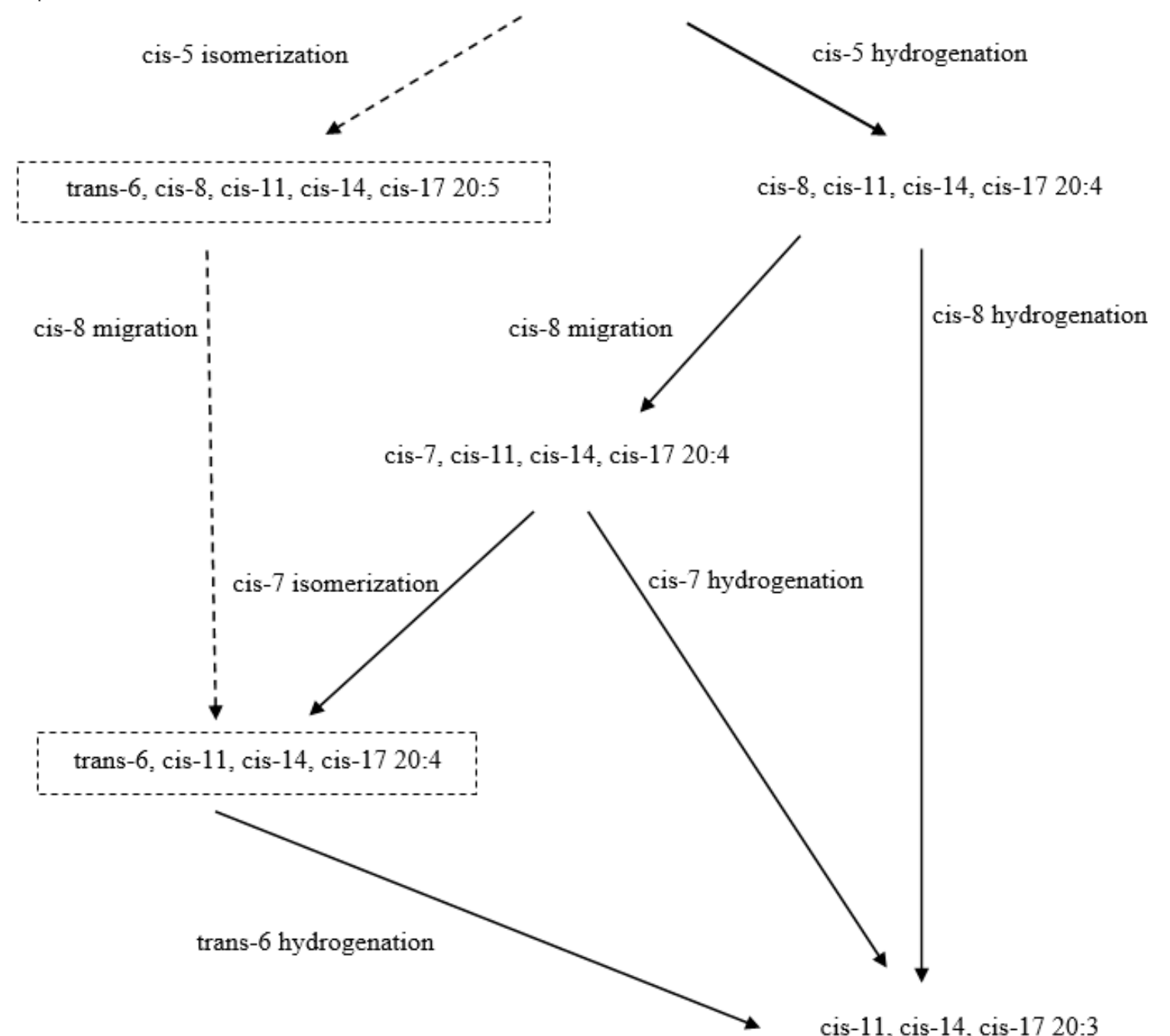

Figure 3. Possible biohydrogenation pathways of 20:5n-3. Solid arrows represent possible major pathway; dotted lines with arrows represents hypothetical pathway (adapted from Toral et al. [95]).

\section{Recent Attempts to Increase n-3 PUFA Content In Dairy-Derived Products}

Up to the present time, the nutritional manipulation of feeding regimes and supplementation with lipid sources containing high amounts of n-3 PUFA $[17,96]$ are the major approaches to improving n-3 PUFA content in dairy products. In contrast, current efforts to employ genetic programmes in this theme have not yet yielded significant enhancement because the FA profile of milk processed products primarily depends on the FA composition of raw milk [97-99]. Therefore, current studies mostly focus on milk content as the principal route of increasing n-3 PUFA in other processed products.

\subsection{Feeding Regime}

Previous studies had demonstrated that feeding regime, particularly changes in forage sources and feeding systems, had significant effects on shorter chain n-3 PUFA, but minor effects on n-3 LC-PUFA concentrations in both dairy ewes and cows (Table 3). This is because lipids from pasture sources contain abundant amounts of ALA [100,101], but not EPA, DHA and DPA. For example, ALA content of fresh ryegrass varieties, a popular pasture used for ruminants worldwide, ranges from 62 to $74 \%$ of total fatty acids [102]. However, the pasture conservation processes, particularly grass wilting in the field, generally cause the oxidative loss of forage PUFA, subsequently and markedly reducing 
the content of ALA in hay or silage [100]. Wilting ryegrass $24 \mathrm{~h}$ in glasshouse, for instance, reduced the percentage of ALA by 33\% compared to unwilted grass [103]. Therefore, dairy ruminants that are kept in grazing systems or have free access to fresh grass produced much higher proportions of ALA in milk compared with animals fed conserved grass (hay and silage) [104-107]. These results appear to be supported by the higher ALA intake of animals fed or grazed on fresh pastures.

cis-9, cis-12, cis-15 18:3

(alpha-linolenic acid, ALA)

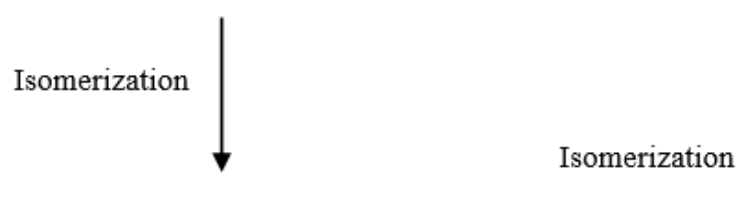

cis-9, trans-11, cis-15 18:3

cis- 9 , trans- 11 , trans-15 18:3

(rumelenic acid)
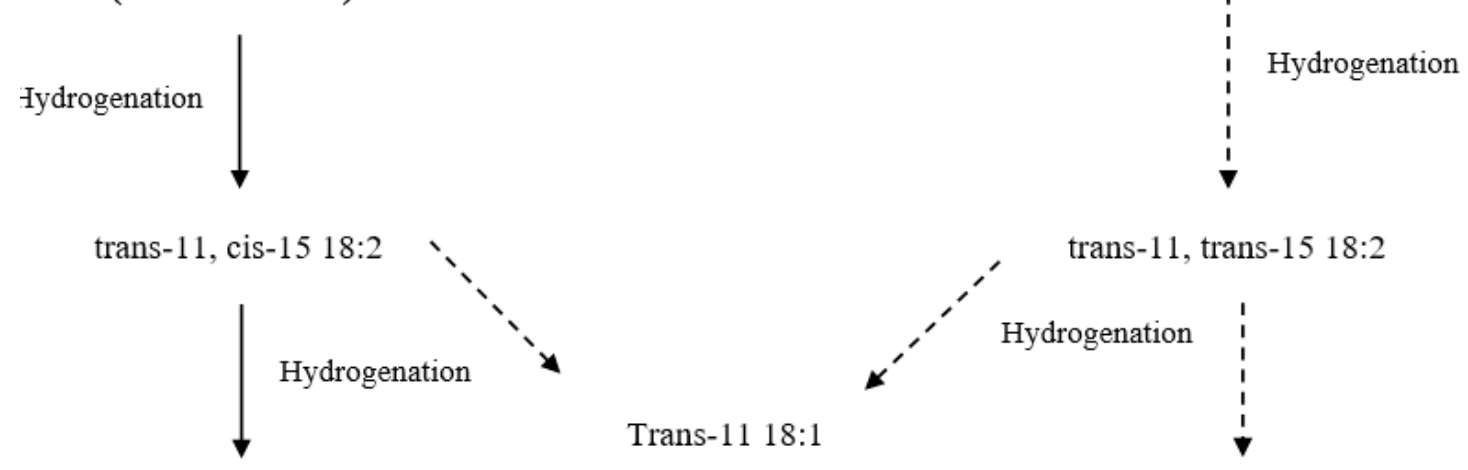

trans-11, trans-15 18:2

Hydrogenation

Trans-11 18:1

cis-15 18:1

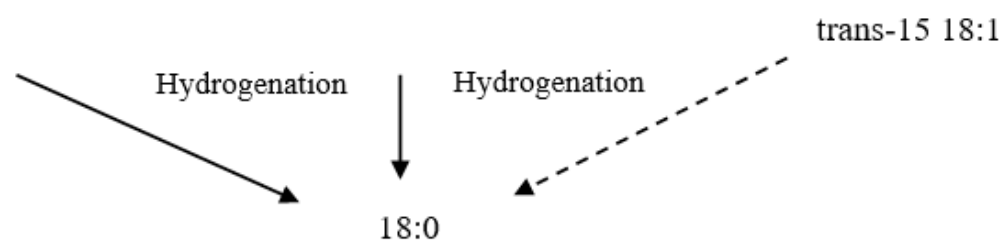

(stearic acid)

Figure 4. Ruminal biohydrogenation of alpha-linolenic acid. Thick arrows represent the major pathway; dotted lines with arrows represent putative pathway (adapted from Gomez-Cortes et al. [108]).

The transfer of n-3 PUFA from forage into milk and milk products is also influenced by forage species (Table 3). Grazing dairy cows on diverse alpine pastures produced more ALA in their milk than on ryegrass-dominated paddocks (1.15 vs. $0.70 \mathrm{~g} / 100 \mathrm{~g}$ FA) [105]. Both Addis et al. [109] and Bonanno et al. [110] reported the greatest concentration of ALA in sheep milk and cheese from ewes grazed on Sulla pasture, versus other common forages including ryegrass, burr medic and daisy forb. Guzatti et al. [111] showed higher levels of ALA in ewe milk for animals fed on clover silage compared with lucerne silage (0.92 vs. $0.70 \mathrm{~g} / 100 \mathrm{~g}$ FA). Disparities observed between forage species in the transfer of n-3 PUFA into milk in these studies were not correlated with ALA intake, but were associated with variation in condensed tannin content in the forages. The most possible mechanisms and effects of the condensed tannins were explained by Cabiddu et al. [112], in which tannins inhibited rumen microbial activities, thus ultimately lowering the PUFA biohydrogenation process in the rumen. The attempt to reduce microbial species involved in biohydrogenation such as B. proteoclasticus has been implemented with limited success due to many factors. For more details, see comprehensive coverage by Lourenco et al. [113]. 


\subsection{Lipid Supplementation}

Lipid supplementation has been used as an effective tool to improve animal performance due to its significant energy contribution [101], and it can also alter milk fat composition because of the high content of essential FA [114,115]. Fish oils and marine products, oilseeds and vegetable oils are the main sources that have been employed in ruminant diets to enhance the concentrations of health beneficial n-3 PUFA and n-3 LC-PUFA in milk and milk products [101].

\subsubsection{Oil Seed and Vegetable Oil}

Plant-derived fat is the most common fat source in ruminant supplements, and includes both oilseeds and extracted vegetable oils. This is because these materials not only contain a high concentration of PUFA [116], protein and energy [117], but are also more readily available and cheaper than other (marine) sources [22]. Therefore, a number of studies have examined the effects of oilseed and vegetable oils on the concentration of health beneficial n-3 PUFA in both bovine and ovine milk products (Table 4). Based on previously reported results, the addition of flaxseed or linseed supplements in ruminant diets is a more effective strategy to enrich milk n-3 PUFA compared to other plant fat supplementation methods (Table 4). Due to its very high content in ALA at approximately $53 \%$ of all FA [118], cows or sheep supplemented with flaxseed had substantial enhancement of this shorter chain n-3 PUFA in milk products (Table 4).

Table 3. Effect of pasture feeding regimes on $\mathrm{n}-3$ PUFA content of milk (g/100 g fatty acids).

\begin{tabular}{|c|c|c|c|c|c|c|}
\hline Forage Source/Feeding System & Species & ALA & EPA & DHA & DPA & References \\
\hline Ryegrass-dominated pastures & Bovine & 0.703 & 0.083 & 0.009 & 0.109 & Leiber et al. [105] \\
\hline Freshly harvested ryegrass & & 0.619 & 0.073 & 0.009 & 0.113 & \\
\hline Alpine pastures & & 1.146 & 0.083 & 0.009 & 0.120 & \\
\hline Freshly harvested Alpine & & 0.950 & 0.083 & 0.010 & 0.118 & \\
\hline Silage-concentrate diet (control) ${ }^{1}$ & & 0.516 & 0.063 & ND & 0.082 & \\
\hline Ryegrass pasture & Bovine & 0.68 & 0.05 & 0.02 & 0.07 & Mohammed et al. [107] \\
\hline Freshly harvested ryegrass & & 0.82 & 0.07 & 0.02 & 0.08 & \\
\hline Ryegrass silage & & 0.34 & 0.05 & 0.02 & 0.09 & \\
\hline Indoor hay based diet & Bovine & 0.72 & 0.08 & - & 0.147 & Coppa et al. [119] \\
\hline Rotational grazing system & & 0.727 & 0.070 & - & 0.137 & \\
\hline Continuous grazing system & & 0.940 & 0.087 & - & 0.150 & \\
\hline Indoor conventional system & Bovine & 0.579 & 0.072 & - & 0.118 & Stergiadis et al. [120] \\
\hline Indoor organic system & & 1.199 & 0.098 & - & 0.098 & \\
\hline Mixed forage ${ }^{2}$ & Bovine & 0.47 & - & - & - & Liu et al. [121] \\
\hline Corn stalk1 diet (35\%) & & 0.58 & - & - & - & \\
\hline Corn stalk2 diet (53.8\%) & & 0.63 & - & - & - & \\
\hline Daisy forb - winter & Ovine & 1.62 & - & - & - & Addis et al. [109] \\
\hline Ryegrass - winter & & 1.47 & - & - & - & \\
\hline Burr medic - winter & & 2.19 & - & - & - & \\
\hline Sulla - winter & & 2.98 & _- & - & - & \\
\hline Daisy forb - spring & & 1.26 & - & - & - & \\
\hline Ryegrass - spring & & 1.44 & - & - & - & \\
\hline Burr medic - spring & & 1.84 & - & - & - & \\
\hline Sulla - spring & & 3.15 & - & - & - & \\
\hline Pasture & Ovine & 1.07 & 0.06 & - & 0.13 & Gomez-Cortes et al. [104] \\
\hline Pasture + oat grain & & 0.59 & 0.05 & - & 0.12 & \\
\hline Total mixed ration ${ }^{3}$ & & 0.33 & 0.03 & - & 0.06 & \\
\hline Grass hay (in door) & Ovine & 1.31 & 0.19 & 0.30 & - & Mierlita [106] \\
\hline Part-time grazing & & 2.06 & 0.28 & 0.39 & - & \\
\hline $\begin{array}{l}\text { Pasture } \\
\text { Pas }\end{array}$ & Ovine & 2.09 & 0.30 & 0.37 & - & Mierlita et al. [122] \\
\hline Pasture + standard concentrate $^{3}$ & & 1.04 & 0.11 & 0.18 & - & \\
\hline Pasture & Ovine & 0.44 & 0.01 & 0.07 & 0.13 & Mohamed et al. [123] \\
\hline Pasture + concentrate & & 0.24 & 0.00 & 0.12 & 0.07 & \\
\hline Concentrate & & 0.21 & 0.00 & 0.00 & 0.08 & \\
\hline Red clover silage & Ovine & 0.92 & 0.05 & - & 0.09 & Guzatti et al. [111] \\
\hline Lucerne silage & & 0.70 & 0.05 & - & 0.09 & \\
\hline
\end{tabular}

1 The control diet contained $60 \%$ ryegrass silage, $30 \%$ maize silage and $10 \%$ grass hay on dry matter basis. ${ }^{2}$ Mixed forage contained $26.7 \%$ corn silage, $23.4 \%$ alfalfa hay and $3.7 \%$ Chinese wild rye on dry matter basis. ${ }^{3}$ Total mixed ration contained concentrate and forage in proportion of 80:20. 
Oil infusion is also considered an effective form of providing plant oil supplements that increases the escape rate of UFA from the BH of rumen microbes, thus enhancing the availability of $n-3$ PUFA for absorption [17]. Khas et al. [124] reported that adding $160 \mathrm{~g} /$ day of infused free ALA in the diet for lactating cows increased ALA content in milk by 41 -fold, and also resulted in significant increases in milk EPA and DPA by two-fold and three-fold, respectively. However, supplementation with vegetable seed and oils only marginally increased milk EPA, DHA, and DPA in both bovines and ovines, with the percentages of these FA often lower than $0.1 \mathrm{~g} / 100 \mathrm{~g}$ FA (Table 4). These findings indicated that the endogenous biosynthesis pathway of these n-3 LC-PUFA from dietary ALA in dairy animals is limited.

\subsubsection{Marine Lipid Sources}

Feeding dairy animals with marine oil resulted in the highest n-3 LC-PUFA concentration in milk and milk products (Table 5) among all types of lipid supplements examined. Previous studies also confirmed the efficiency of utilising rumen-protected forms of marine products that were markedly higher than in the untreated controls; mainly as a result of the lesser extent of ruminal biohydrogenation with the rumen-protected diets [125]. Kitessa et al. reported that the content of EPA and DHA, which are generally scanty in milk (Tables 3 and 4), could be increased by supplementing both dairy cattle [126] and ewes [127] with rumen-protected fish oil. The proportion of DHA, the most essential n-3 LC-PUFA, observed in these studies, exceeded $1 \%$ of the total FA. Similarly, an effective incorporation rate of DHA from a marine algae supplement, an alternative to fish oil into milk, was also confirmed by a number of studies (Table 5). This transfer rate appears to be higher as observed in ovine [128] than in bovine [129]. Results presented in Table 5 also indicate that supplementing fish oil is more advantageous than marine algae in terms of improving milk EPA and DPA content.

Recent focus on achieving quantitatively significant amounts of n-3 PUFA per standard serve of milk and milk products has occurred $[45,46]$. This absolute FA concentration data may be more accurate than the proportion (expressed as \%FA) itself, since the fat percentage of milk from different species varies widely [130], and such quantitative data can potentially assist consumers in purchasing decisions. One serve of fresh milk produced from grazing ewes supplemented with rumen-protected EPA + DHA contains $62 \mathrm{mg}$ of total n-3 LC-PUFA, three-fold higher than the control group [45]. This result is higher than the concentration of total EPA + DHA + DPA in one serve of cooked lamb meat (55 mg) reported by Flakemore et al. [131]. In achieving $60 \mathrm{mg} /$ serving, this sheep milk can also be considered as achieving a "good source" level of n-3 LC-PUFA, adhering to Food Standards Australia and New Zealand (FSANZ) [132]. Although the inclusion of fish oil into ruminant diets might have a negative effect on meat quality such as possible rancidity and abnormal flavour in cooked or grilled lamb [133], no side effects on milk and milk products have been reported. Nguyen et al. [46] observed no differences in sensory eating traits between ripened cheese processed from milk produced by dairy sheep supplemented with rumen-protected marine source and the unsupplemented group. However, the higher cost of the marine oil source possibly limits its utilization as a routine supplementation for dairy ruminants [101]. 
Table 4. Effect of supplementing ruminants with plant-derived dietary sources on n-3 PUFA concentration in milk and milk products (g/100 g fatty acids).

\begin{tabular}{|c|c|c|c|c|c|c|c|}
\hline Diet & Species & Product & ALA & EPA & DHA & DPA & References \\
\hline Control & \multirow{5}{*}{ Bovine } & \multirow{5}{*}{ Milk } & 0.61 & 0.09 & - & 0.07 & \multirow{5}{*}{ Khas et al. [124] } \\
\hline $40 \mathrm{~g} /$ day infused LNA-rich fatty acid & & & 6.49 & 0.18 & - & 0.12 & \\
\hline $80 \mathrm{~g} /$ day infused LNA-rich fatty acid & & & 12.42 & 0.22 & - & 0.16 & \\
\hline $120 \mathrm{~g} /$ day infused LNA-rich fatty acid & & & 18.75 & 0.21 & - & 0.29 & \\
\hline $160 \mathrm{~g} /$ day infused LNA-rich fatty acid & & & 25.38 & 0.22 & - & 0.23 & \\
\hline Control & \multirow{2}{*}{ Bovine } & \multirow{2}{*}{ Milk } & 0.75 & 0.003 & 0.001 & - & \multirow{2}{*}{ Caroprese et al. [134] } \\
\hline Whole flaxseed & & & 0.81 & 0.022 & 0.001 & - & \\
\hline Control & \multirow{4}{*}{ Bovine } & \multirow{4}{*}{ Milk } & 0.41 & 0.05 & - & 0.05 & \multirow{4}{*}{ Dai et al. [135] } \\
\hline Rapeseed oil & & & 0.38 & 0.06 & - & 0.04 & \\
\hline Peanut oil & & & 0.33 & 0.06 & - & 0.06 & \\
\hline Sunflower seed oil & & & 0.32 & 0.06 & - & 0.05 & \\
\hline Control & \multirow{4}{*}{ Bovine } & \multirow{4}{*}{ Milk } & 0.83 & 0.09 & 0.01 & 0.13 & \multirow{4}{*}{ Otto et al. [136] } \\
\hline $25 \mathrm{~mL} / \mathrm{kg} \mathrm{DM}^{1}$ Canola oil & & & 0.85 & 0.09 & 0.01 & 0.14 & \\
\hline 35 mL/kg DM canola oil & & & 0.95 & 0.08 & 0.01 & 0.12 & \\
\hline $50 \mathrm{~mL} / \mathrm{kg}$ DM canola oil & & & 0.97 & 0.08 & 0.00 & 0.11 & \\
\hline Control & \multirow{3}{*}{ Bovine } & & 0.28 & 0.02 & - & - & \\
\hline $500 \mathrm{~g} /$ day extruded flaxseed & & Milk & 0.50 & 0.02 & - & - & Cattani et al. [137] \\
\hline $1000 \mathrm{~g} /$ day extruded flaxseed & & & 0.59 & 0.02 & - & - & \\
\hline Linseed oil & & & 0.249 & 0.019 & - & 0.014 & \\
\hline Safflower oil & Bovine & Milk & 0.180 & 0.013 & - & 0.007 & Li et al. [138] \\
\hline Control & & & 0.19 & 0.012 & 0.004 & 0.037 & \\
\hline $3 \%$ Canola oil & Bovine & Milk & 0.36 & 0.011 & 0.003 & 0.034 & Welter et al. [139] \\
\hline $6 \%$ Canola oil & & & 0.35 & 0.011 & 0.003 & 0.033 & \\
\hline Control & & & 0.19 & - & 0.019 & - & Vanbergue et al. [140] \\
\hline Extruded linseed & Bovine & Milk & 0.51 & - & 0.008 & - & Vanbergue et al. [140] \\
\hline Palm oil & & & 0.52 & 0.04 & 0.02 & 0.08 & \\
\hline Olive oil & & & 0.36 & 0.03 & 0.02 & 0.06 & \\
\hline Soybean oil & Ovine & Milk & 0.53 & 0.03 & 0.02 & 0.07 & Bodas et al. [141] \\
\hline Linseed oil & & & 1.07 & 0.05 & 0.04 & 0.11 & \\
\hline Control & & & 1.21 & 0.05 & 0.05 & - & \\
\hline $100 \mathrm{~g}$ extruded linseed & Ovine & Milk & 1.65 & 0.06 & 0.09 & - & Mughetti et al. [142] \\
\hline $200 \mathrm{~g}$ extruded linseed & & & 2.26 & 0.06 & 0.10 & - & \\
\hline Control & & & 0.57 & 0.07 & 0.05 & 0.08 & \\
\hline Seaweed & & & 0.59 & 0.06 & 0.04 & 0.08 & \\
\hline Whole flaxseed & Ovine & Milk & 1.53 & 0.08 & 0.05 & 0.09 & Caroprese et al. [143] \\
\hline Seaweed + Whole flaxseed & & & 1.32 & 0.08 & 0.06 & 0.10 & \\
\hline Control & & & 0.62 & 0.08 & 0.04 & 0.08 & \\
\hline Canola oil & & & 0.73 & 0.09 & 0.06 & 0.13 & \\
\hline Rice bran oil & Ovine & Milk & 0.51 & 0.07 & 0.04 & 0.10 & Nguyen et al. [45] \\
\hline Flaxseed oil & & & 1.74 & 0.11 & 0.06 & 0.15 & \\
\hline Safflower oil & & & 0.67 & 0.07 & 0.06 & 0.10 & \\
\hline Control & & & 0.31 & 0.04 & 0.02 & 0.08 & \\
\hline Canola oil & & & 0.26 & 0.03 & 0.02 & 0.07 & \\
\hline Sunflower oil & Ovine & Milk & 0.24 & 0.03 & 0.02 & 0.07 & Parentet et al. [144] \\
\hline Castor oil & & & 0.28 & 0.05 & 0.01 & 0.08 & \\
\hline Control & & & 0.29 & 0.02 & - & - & \\
\hline $500 \mathrm{~g} /$ day extruded Flaxseed at & Bovine & Cheese & 0.50 & 0.02 & - & - & Cattani et al. [137] \\
\hline $1000 \mathrm{~g} /$ day extruded Flaxseed at & & & 0.61 & 0.02 & - & - & \\
\hline Palm oil & & & 0.54 & 0.04 & 0.02 & 0.07 & \\
\hline Olive oil & & & 0.36 & 0.03 & 0.03 & 0.06 & \\
\hline Soybean oil & Ovine & Cheese & 0.51 & 0.03 & 0.02 & 0.06 & Bodas et al. [141] \\
\hline Linseed oil & & & 1.04 & 0.03 & 0.03 & 0.09 & \\
\hline Control & & & 1.18 & 0.02 & 0.03 & - & \\
\hline $100 \mathrm{~g}$ extruded linseed & Ovine & Cheese & 1.84 & 0.04 & 0.05 & - & Mughettiet al. [142] \\
\hline $200 \mathrm{~g}$ extruded linseed & & & 2.02 & 0.04 & 0.06 & - & \\
\hline Control & & & 0.71 & 0.11 & 0.06 & 0.12 & \\
\hline Canola oil & & & 0.79 & 0.11 & 0.06 & 0.13 & \\
\hline Rice bran oil & Ovine & Cheese & 0.63 & 0.10 & 0.06 & 0.12 & Nguyen et al. [46] \\
\hline Flaxseed oil & & & 1.30 & 0.11 & 0.06 & 0.13 & \\
\hline Safflower oil & & & 0.71 & 0.11 & 0.08 & 0.13 & \\
\hline Control & & & 0.0 & - & - & - & \\
\hline 2\% Palm oil & & & 0.0 & - & - & - & \\
\hline $4 \%$ Palm oil & Ovine & Yogurt & 0.28 & - & - & - & Bianchi et al. [145] \\
\hline $6 \%$ Palm oil & & & 0.31 & - & - & - & \\
\hline
\end{tabular}

${ }^{1}$ DM: dry matter.

\subsection{Genetic Manipulation as a Potential Tool for the Enrichment of Dairy Products with n-3 PUFA}

Attempts at understanding and estimating genetic parameters influencing milk FA content that may be beneficial for human health had been made a decade ago $[146,147]$. Up to the present 
time, low heritabilities ( $<0.1$ ) for individual n-3 PUFA (Table 6) were consistently reported in dairy cows [147-149] and dairy sheep [150], indicating a low impact of genetics or breed on the concentration of n-3 PUFA. This observation probably arises because the fatty acids longer than 18 carbon chains are not de novo synthesized in the mammary gland, but are circulated from the blood which contains lipids that originated from the diet [94]. Moderate heritabilities for the whole group of n-3 PUFA were reported by Boichard et al. [151] and Maroteau et al. [152], and could be explained by major contribution of the shorter chain n-3 PUFA. First identified in the human genome in 2000 [153], fatty acid desaturase 1 and 2 (FADS1 and FADS2) are considered as the major candidate genes that regulate the endogenous synthesis of n-3 LC-PUFA from ALA in mammals including ruminants [154-158]. The first effort to define the association between these two encoding genes and n-3 PUFA in the milk of Holstein cows [159] found that three significant single nucleotide polymorphism (SNP) markers within FADS1 and FADS2 were associated with EPA. Apart from the two well-characterized FADS1 and FADS2 genes, Ibeagha-Awemu et al. [160] uncovered more potential candidate genes with several novel SNPs that were significantly associated with milk EPA and DPA. Consequently, by employing these potential genetic markers, future research can investigate the specific relationships between combining genetics and other environmental strategies such as nutritional supplementation for elevating n-3 LC PUFA in milk.

Table 5. Effect of supplementing ruminants with dietary marine sources on n-3 PUFA concentration of milk and milk products $(\mathrm{g} / 100 \mathrm{~g}$ fatty acids).

\begin{tabular}{|c|c|c|c|c|c|c|c|}
\hline Diet & Species & Product & ALA & EPA & DHA & DPA & References \\
\hline Control & \multirow{3}{*}{ Bovine } & \multirow{3}{*}{ Milk } & 0.54 & - & 0.00 & - & \multirow{3}{*}{ Franklin et al. [161] } \\
\hline Protected algae & & & 0.49 & - & 0.76 & - & \\
\hline Unprotected algae & & & 0.47 & - & 0.46 & - & \\
\hline Control & \multirow{2}{*}{ Bovine } & \multirow{2}{*}{ Milk } & 0.86 & 0.0 & 0.0 & - & \multirow{2}{*}{ Kitessa et al. [126] } \\
\hline Rumen-protected tuna oil & & & 1.28 & 0.61 & 1.09 & - & \\
\hline Control & \multirow{2}{*}{ Bovine } & \multirow{2}{*}{ Milk } & 0.21 & 0.03 & 0.00 & 0.07 & \multirow{2}{*}{ Shingfield et al. [162] } \\
\hline Fish oil and sunflower oil & & & 0.23 & 0.11 & 0.07 & 0.16 & \\
\hline Control & \multirow{2}{*}{ Bovine } & \multirow{2}{*}{ Milk } & 0.50 & - & 0.09 & - & \multirow{2}{*}{ Boeckaert et al. [129] } \\
\hline Marine algae & & & 0.42 & - & 1.01 & - & \\
\hline $\mathrm{ABO} / \mathrm{ABO}^{1}$ & \multirow{4}{*}{ Bovine } & \multirow{4}{*}{ Milk } & 14.4 & 0.22 & - & 0.22 & \multirow{4}{*}{ Kazama et al. [163] } \\
\hline $\mathrm{RUM} / \mathrm{ABO}^{2}$ & & & 4.78 & 0.14 & - & 0.22 & \\
\hline RUM/RUM ${ }^{3}$ & & & 2.33 & 0.09 & - & 0.12 & \\
\hline $\mathrm{ABO} / \mathrm{RUM}^{4}$ & & & 11.6 & 0.16 & - & 0.18 & \\
\hline Control & \multirow{3}{*}{ Bovine } & \multirow{2}{*}{ Milk } & 0.75 & 0.003 & 0.001 & - & \multirow{2}{*}{ Caroprese et al. [134] } \\
\hline Fish oil & & & 0.84 & 0.060 & 0.117 & - & \\
\hline Control & & & 0.45 & 0.06 & 0.10 & - & \\
\hline Fish oil & \multirow[t]{3}{*}{ Bovine } & \multirow[t]{2}{*}{ Milk } & 0.62 & 0.10 & 0.21 & - & \multirow[t]{2}{*}{ Vargas-Bello-Pérez et al. [164] } \\
\hline Fish oil + palm oil & & & 0.69 & 0.09 & 0.14 & - & \\
\hline Control & & \multirow{4}{*}{ Milk } & 0.41 & 0.06 & 0.03 & 0.09 & \\
\hline Ultrarefined fish oil at $75 \mathrm{~g} /$ day & \multirow{4}{*}{ Bovine } & & 0.38 & 0.06 & 0.03 & 0.08 & Kaireniuset al [165] \\
\hline Ultrarefined fish oil at $150 \mathrm{~g} /$ day & & & 0.39 & 0.07 & 0.05 & 0.10 & Kairenius et al. [165] \\
\hline Ultrarefined fish oil at $300 \mathrm{~g} /$ day & & & 0.48 & 0.17 & 0.10 & 0.18 & \\
\hline Control & & & 0.19 & - & 0.019 & - & \\
\hline Microalgae DHA Gold ${ }^{\circledR}$ & Bovine & Milk & 0.25 & - & 0.444 & - & Vanbergue et al. [140] \\
\hline Extruded linseed + DHA Gold ${ }^{\circledR}$ & & & 0.46 & - & 0.170 & - & \\
\hline Control & & & 0.33 & ND & ND & ND & \\
\hline Low algae (23.5 g) & & & 0.31 & 0.04 & 0.43 & 0.21 & \\
\hline Medium algae (47 g) & Ovine & Milk & 0.33 & 0.12 & 0.69 & 0.28 & Papadopoulos et al. [128] \\
\hline High algae (94 g) & & & 0.25 & 0.21 & 1.24 & 0.31 & \\
\hline Control & & & 0.53 & 0.05 & 0.03 & 0.10 & \\
\hline Sunflower oil (SO) & & & 0.41 & 0.04 & 0.02 & 0.07 & \\
\hline $\mathrm{SO}+8 \mathrm{~g} / \mathrm{kg}$ DM of Marine Algae & Ovine & Milk & 0.37 & 0.05 & 0.17 & 0.10 & Toral et al. [166] \\
\hline $\mathrm{SO}+16 \mathrm{~g} / \mathrm{kg}$ DM of Marine Algae & & & 0.36 & 0.09 & 0.46 & 0.13 & \\
\hline $\mathrm{SO}+24 \mathrm{~g} / \mathrm{kg}$ DM of Marine Algae & & & 0.34 & 0.10 & 0.57 & 0.15 & \\
\hline Sunflower oil & & & 0.49 & 0.04 & 0.05 & 0.10 & \\
\hline Sunflower oil + Marine algae & Ovine & Milk & 0.48 & 0.06 & 0.38 & 0.12 & Bichi et al. [167] \\
\hline Control & & & 0.62 & 0.08 & 0.04 & 0.08 & \\
\hline Rumen-protected EPA + DHA oil & Ovine & Milk & 0.74 & 0.17 & 0.19 & 0.23 & Nguyen et al. [45] \\
\hline Control & & & 0.01 & 0.05 & 0.09 & - & \\
\hline Fish oil & Bovine & Cheese & 0.02 & 0.12 & 0.34 & - & Vargas-Bello-Pérez et al. [164] \\
\hline Fish oil + palm oil & & & 0.01 & 0.09 & 0.18 & - & \\
\hline Control & & & 0.71 & 0.11 & 0.06 & 0.12 & \\
\hline Rumen-protected EPA + DHA & Ovine & Cheese & 1.02 & 0.16 & 0.15 & 0.19 & Nguyen et al. [46] \\
\hline
\end{tabular}

${ }^{1} \mathrm{ABO} / \mathrm{ABO}$ diet contains abomasal flax oil and hulls infusion. ${ }^{2}$ RUM/ABO diet contains flax oil placed in the rumen and hulls infused in the abomasum. ${ }^{3}$ RUM/RUM diet contains flax oil and hulls placed in the rumen and abomasal infusion of water. ${ }^{4} \mathrm{ABO} / \mathrm{RUM}$ diet contains flax hulls administered in the rumen and abomasal flax oil infusion. 
Table 6. Heritability estimates of major individual and group of n-3 fatty acids.

\begin{tabular}{llllllll}
\hline Breed & Species & Unit & ALA & EPA & DPA & n-3 & Reference \\
\hline Holstein-Friesians & Bovine & \%FA & 0.09 & - & - & - & Stoop et al. [147] \\
Holsteins & Bovine & \% FA & 0.06 & 0.04 & 0.01 & - & Bilal et al. [148] \\
Brown Swiss & Bovine & \% FA & 0.093 & 0.045 & 0.039 & 0.085 & Pegolo et al. [149] \\
Sarda & Ovine & $\%$ FA & 0.02 & - & - & - & Correddu et al. [150] \\
Holstein & Bovine & & - & - & - & 0.26 & \\
Saanen & Caprine & $\%$ fat & - & - & - & 0.23 & Boichard et al. [151] \\
Lacaune & Ovine & & - & - & - & 0.18 & \\
Alpine & Caprine & & - & - & - & 0.28 & Maroteau et al. [152] \\
Saanen & Caprine & $\%$ fat & - & - & - & 0.25 & \\
\hline
\end{tabular}

\section{Conclusions}

Since first being reported some four decades ago, the number of studies confirming the beneficial effects of n-3 PUFA on reducing the risk of chronic diseases including cardiovascular disease, cancer, mental illnesses, age-related cognitive decline, and inflammatory diseases were over and above those that found neutral or adverse effects. Specific mechanisms with respect to the independent and/or supplementary influences of n-3 PUFA on human health, however, remain controversial and need further investigations. Consumption of seafood as the major source of n-3 LC-PUFA is still generally insufficient, resulting in the need for enhancing the concentration of these beneficial n-3 LC-PUFA in other common dietary sources for human consumption. Attempts to increase the content of $n-3$ LC-PUFA in milk and milk products, which are important components of the human diet, has therefore been a major research focus for the last two decades. Current studies generally demonstrate that the processes of lipolysis combined with dietary lipid BH in the rumen are the main obstacles in modulating n-3 LC-PUFA content of dairy products. In addition, the biosynthetic pathway of these FA from the precursor ALA, is limited, with only minor conversion occurring. Thus, supplementing ruminants with marine-derived sources in a rumen-protected form is at this time, one of the best strategies to increase n-3 LC-PUFA content in milk and its processed products. Yet, there seems to be a lack of evaluation regarding the economic efficiency of different supplemented ingredients utilized in the current research. We propose that further studies are required to better elucidate the n-3 LC-PUFA biosynthesis pathway from ALA, together with the $\mathrm{BH}$ mechanism of individual n-3 LC-PUFA. A more comprehensive knowledge of these aspects would be a guiding principle for further research on increasing the escape rate of dietary PUFA from the rumen and their absorption rate from the small intestine into milk. Genetically modifying oilseeds as an alternative and sustainable source of dietary n-3 LC-PUFA for ruminants should be taken into account when future supplies of fish oil may not be sufficient. Finally, activities of regulated genes on the concentration of n-3 PUFA and their reaction to non-genetic factors such as lipid supplementation for specific dairy species also needs to be better defined. Identified knowledge gaps regarding the activities of candidate genes regulating the concentrations of n-3 PUFA and the responses of ruminants to specific lipid supplementation regimes are also critical to a greater understanding of nutrition-genetics interactions driving lipid metabolism.

Author Contributions: Conceptualization, A.E.O.M.-A., P.D.N., J.C. and B.S.M.-A.; methodology, A.E.O.M.-A., P.D.N., B.S.M.-A., J.C. and Q.V.N.; software, A.E.O.M.-A.; validation, A.E.O.M.-A., P.D.N., J.C. and B.S.M.-A.; formal analysis, Q.V.N.; investigation, Q.V.N.; resources, A.E.O.M.-A.; data curation, A.E.O.M.-A., P.D.N. and Q.V.N.; writing—original draft preparation, Q.V.N.; writing—review and editing, A.E.O.M.-A., P.D.N., J.C. and B.S.M.-A.; supervision, A.E.O.M.-A., P.D.N., J.C. and B.S.M.-A.; project administration, A.E.O.M.-A.; funding acquisition, A.E.O.M.-A.

Funding: This research was funded by Australian Awards PhD Scholarship from the Australian Government's Department of Foreign Affairs and Trade awarded to the first-named author and the APC was funded by the College of Public Health, Medical and Veterinary Sciences, James Cook University, Queensland, Australia.

Acknowledgments: In addition to the funding body, the first-named author gratefully acknowledges supervisors at the Veterinary Sciences Discipline, College of Public Health, Medical and Veterinary Sciences, James Cook 
University, Queensland, Australia, for their editorial, technical and academic assistance before, during and after writing the draft of this literature review.

Conflicts of Interest: The authors declare no conflict of interest. The funders had no role in the design of the study; collection, analyses, or interpretation of data; in the writing of the manuscript, or in the decision to publish the results.

\section{References}

1. Nichols, P.D.; Petrie, J.; Singh, S. Long-chain omega-3 oils-an update on sustainable sources. Nutrients 2010, 2, 572-585. [CrossRef]

2. Bang, H.O.; Dyerberg, J.; Sinclair, H.M. The composition of the Eskimo food in north western Greenland. Am. J. Clin. Nutr. 1980, 33, 2657-2661. [CrossRef] [PubMed]

3. Calder, P.C. Very long chain omega-3 (n-3) fatty acids and human health. Eur. J. Lipid. Sci. Technol. 2014, 116, 1280-1300. [CrossRef]

4. McGuire, M.A.; McGuire, M.K. Conjugated linoleic acid (CLA): A ruminant fatty acid with beneficial effects on human health. J. Anim. Sci. 2000, 77, 1-8. [CrossRef]

5. Calder, P.C. Long-chain fatty acids and inflammation. Proc. Nutr. Soc. 2012, 71, 284-289. [CrossRef]

6. Calder, P.C. Omega-3 polyunsaturated fatty acids and inflammatory processes: Nutrition or pharmacology? Br. J. Clin. Pharmacol. 2013, 75, 645-662. [CrossRef]

7. Belury, M.A. Inhibition of carcinogenesis by conjugated linoleic acid: Potential mechanisms of action. J. Nutr. 2002, 132, 2995-2998. [CrossRef]

8. Calder, P.C. n-3 fatty acids and cardiovascular disease: Evidence explained and mechanisms explored. Clin. Sci. 2004, 107, 1-11. [CrossRef] [PubMed]

9. Calon, F.; Cole, G. Neuroprotective action of omega-3 polyunsaturated fatty acids against neurodegenerative diseases: Evidence from animal studies. Prostaglandins Leukot. Essent. Fatty Acids 2007, 77, 287-293. [CrossRef]

10. Kalmijn, S.; Launer, L.J.; Ott, A.; Witteman, J.C.M.; Hofman, A.; Breteler, M.M.B. Dietary fat intake and the risk of incident dementia in the Rotterdam Study. Ann. Neurol. 1997, 42, 776-782. [CrossRef] [PubMed]

11. Laugharne, J.D.E.; Mellor, J.E.; Peet, M. Fatty acids and schizophrenia. Lipids 1996, 31, 163-165. [CrossRef]

12. Byelashov, O.A.; Sinclair, A.J.; Kaur, G. Dietary sources, current intakes, and nutritional role of omega-3 docosapentaenoic acid. Lipid Technol. 2015, 27, 79-82. [CrossRef] [PubMed]

13. WHO. Non-Communicable Diseases Country Profiles 2018; Licence: CC BY-NC-SA 3.0 IGO; World Health Organization: Geneva, Switzerland, 2018.

14. Simopoulos, A.P. Evolutionary aspects of diet: The omega-6/omega-3 ratio and the brain. Mol. Neurobiol. 2011, 44, 203-215. [CrossRef]

15. Cordain, L.; Eaton, S.B.; Sebastian, A.; Mann, N.; Lindeberg, S.; Watkins, B.A.; O'Keefe, J.H.; Brand-Miller, J. Origins and evolution of the Western diet: Health implications for the 21st century. Am. J. Clin. Nutr. 2005, 81, 341-354. [CrossRef]

16. Kennedy, E.T.; Luo, H.; Ausman, L.M. Cost implications of alternative sources of (n-3) fatty acid consumption in the United States. J. Nutr. 2012, 142, 605S-609S. [CrossRef]

17. Shingfield, K.J.; Bonnet, M.; Scollan, N.D. Recent developments in altering the fatty acid composition of ruminant-derived foods. Animal 2013, 7, 132-162. [CrossRef]

18. Rozenberg, S.; Body, J.J.; Bruyere, O.; Bergmann, P.; Brandi, M.; Cooper, C.; Devogelaer, J.P.; Gielen, E.; Goemaere, S.; Kaufman, J.M.; et al. Effects of dairy products consumption on health: Benefits and beliefs-a commentary from the Belgian bone club and the European society for clinical and economic aspects of osteoporosis, osteoarthritis and musculoskeletal diseases. Calcif. Tissue Int. 2016, 98, 1-17. [CrossRef]

19. Burgess, K. Milk and Dairy Products in Human Nutrition; Muehlhoff, E., Bennett, A., McMahon, D., Eds.; Food and Agriculture Organisation of the United Nations (FAO): Rome, Italy, 2013; Volume 67, p. 303, ISBN 978-92-5-107864-8.

20. Kardas, M.; Grochowska-Niedworok, E.; Calyniuk, B.; Kolasa, I.; Grajek, M.; Bielaszka, A.; Kiciak, A.; Muc-Wierzgon, M. Consumption of milk and milk products in the population of the Upper Silesian agglomeration inhabitants. Food Nutr. Res. 2016, 60, 28976. [CrossRef]

21. OECD/FAO. OECD-FAO Agricultural Outlook 2017-2026; OECD Publishing: Paris, France, 2017. [CrossRef] 
22. Nguyen, D.V.; Malau-Aduli, B.S.; Cavalieri, J.; Nichols, P.D.; Malau-Aduli, A.E.O. Supplementation with plant-derived oils rich in omega-3 polyunsaturated fatty acids for lamb production. Vet. Anim. Sci. 2018, 6, 29-40. [CrossRef]

23. NHMRC (National Health and Medical Research Council). Nutrient Reference Values for Australia and New Zealand including Recommended Dietary Intakes; Commonwealth Department of Health and Ageing: Canberra, Australia, 2006.

24. FAO/WHO 2008. Interim Summary of Conclusions and Dietary Recommendations on Total Fat E Fatty Acids; Joint FAO/WHO Expert Consultation on Fats and Fatty Acids in Human Nutrition; WHO: Geneva, Switzerland. Available online: https://www.who.int/nutrition/topics/FFA_summary_rec_conclusion.pdf?ua=1 (accessed on 25 December 2018).

25. Miller, M.; Stone, N.J.; Ballantyne, C.; Bittner, V.; Criqui, M.H.; Ginsberg, H.N.; Goldberg, A.C.; Howard, W.J.; Jacobson, M.S.; Kris-Etherton, P.M.; et al. Triglycerides and cardiovascular disease: A scientific statement from the American Heart Association. Circulation 2011, 123, 2292-2333. [CrossRef]

26. Lee, J.M.; Lee, H.; Kang, S.; Park, W.J. Fatty acid desaturases, polyunsaturated fatty acid regulation, and biotechnological advances. Nutrients 2016, 8, 23. [CrossRef]

27. Baker, E.J.; Miles, E.A.; Burdge, G.C.; Yaqoob, P.; Calder, P.C. Metabolism and functional effects of plant-derived omega-3 fatty acids in humans. Prog. Lipid Res. 2016, 64, 30-56. [CrossRef] [PubMed]

28. Office of Dietary Supplements, National Institute of Health (NIH). Omega-3 Fatty Acids. Available online: https://ods.od.nih.gov/factsheets/Omega3FattyAcids-HealthProfessional/\#en77 (accessed on 21 January 2019).

29. Sprecher, H. The roles of anabolic and catabolic reactions in the synthesis and recycling of polyunsaturated fatty acids. Prostaglandins Leukot. Essent. Fatty Acids 2002, 67, 79-83. [CrossRef] [PubMed]

30. Park, W.J.; Kothapalli, K.S.; Lawrence, P.; Tyburczy, C.; Brenna, J.T. An alternate pathway to long-chain polyunsaturates: The FADS2 gene product Delta8-desaturates 20:2n-6 and 20:3n-3. J. Lipid Res. 2009, 50, 1195-1202. [CrossRef]

31. Park, H.G.; Park, W.J.; Kothapalli, K.S.; Brenna, J.T. The fatty acid desaturase 2 (FADS2) gene product catalyzes delta-4 desaturation to yield n-3 docosahexaenoic acid and n-6 docosapentaenoic acid in human cells. FASEB J. 2015, 29, 3911-3919. [CrossRef] [PubMed]

32. Burdge, G.C.; Calder, P.C. Dietary alpha-linolenic acid and health-related outcomes: A metabolic perspective. Nutr. Res. Rev. 2006, 19, 26-52. [CrossRef]

33. Brenner, R.R. Regulatory function of delta6 desaturase-Key enzyme of polyunsaturated fatty acid synthesis. Adv. Exp. Med. Biol. 1977, 83, 85-101. [PubMed]

34. Narce, M.; Poisson, J.P.; Belleville, J.; Chanussot, B. Time-course effects of protein malnutrition on hepatic fatty acids $\Delta 6$ and $\Delta 5$ desaturation in the growing rat. Br. J. Nutr. 1988, 60, 389-402. [CrossRef]

35. Johnson, S.B.; Kramer, T.R.; Briskeanderson, M.; Holman, R.T. Fatty acid pattern of tissue phospholipids in copper and iron deficiencies. Lipids 1989, 24, 141-145. [CrossRef]

36. Simopoulos, A.P. An increase in the omega-6/omega-3 fatty acid ratio increases the risk for obesity. Nutrients 2016, 8, 128. [CrossRef]

37. Tur, J.A.; Bibiloni, M.M.; Sureda, A.; Pons, A. Dietary sources of omega 3 fatty acids: Public health risks and benefits. Br. J. Nutr. 2012, 107, S23-S52. [CrossRef] [PubMed]

38. Nichols, P.D.; Glencross, B.; Petrie, J.R.; Singh, S.P. Readily available sources of long-chain omega-3 oils: Is farmed Australian seafood a better source of the good oil than wild-caught seafood? Nutrients 2014, 6, 1063-1079. [CrossRef] [PubMed]

39. Garcia, P.T.; Pensel, N.A.; Sancho, A.M.; Latimori, N.J.; Kloster, A.M.; Amigone, M.A.; Casal, J.J. Beef lipids in relation to animal breed and nutrition in Argentina. Meat Sci. 2008, 79, 500-508. [CrossRef] [PubMed]

40. Konieczka, P.; Czauderna, M.; Smulikowska, S. The enrichment of chicken meat with omega-3 fatty acids by dietary fish oil or its mixture with rapeseed or flaxseed-Effect of feeding duration. Anim. Feed Sci. Technol. 2017, 223, 42-52. [CrossRef]

41. Dugan, M.E.; Vahmani, P.; Turner, T.D.; Mapiye, C.; Juarez, M.; Prieto, N.; Beaulieu, A.D.; Zijlstra, R.T.; Patience, J.F.; Aalhus, J.L. Pork as a source of omega-3 (n-3) fatty acids. J. Clin. Med. 2015, 4, 1999-2011. [CrossRef] [PubMed] 
42. Nguyen, D.V.; Flakemore, A.R.; Otto, J.R.; Ives, S.W.; Smith, R.W.; Nichols, P.D.; Malau-Aduli, A.E.O. Nutritional value and sensory characteristics of meat eating quality of Australian prime lambs supplemented with pelleted canola and flaxseed oils: Fatty acid profiles of muscle and adipose tissues. Internal Med. Rev. 2017, 3, 1-21.

43. Le, V.H.; Nguyen, D.V.; Nguyen, Q.V.; Malau-Aduli, B.S.; Nichols, P.D.; Malau-Aduli, A.E.O. Fatty acid profiles of muscle, liver, heart and kidney of Australian prime lambs fed different polyunsaturated fatty acids enriched pellets in a feedlot system. Sci. Rep. 2019, 9, 1238. [PubMed]

44. Le, H.V.; Nguyen, Q.V.; Nguyen, D.V.; Otto, J.R.; Malau-Aduli, B.S.; Nichols, P.D.; Malau-Aduli, A.E.O. Enhanced omega-3 polyunsaturated fatty acid contents in muscle and edible organs of Australian prime lambs grazing lucerne and cocksfoot pastures. Nutrients 2018, 10, 1985. [CrossRef] [PubMed]

45. Nguyen, Q.V.; Le, V.H.; Nguyen, D.V.; Malau-Aduli, B.S.; Nichols, P.D.; Malau-Aduli, A.E.O. Supplementing grazing dairy ewes with plant-derived oil and rumen-protected EPA plus DHA pellets enhances health-beneficial n-3 long-chain polyunsaturated fatty acids in sheep milk. Eur. J. Lipid Sci. Technol. 2018, 120, 256. [CrossRef]

46. Nguyen, Q.V.; Van Le, H.; Nguyen, D.V.; Malau-Aduli, B.S.; Nichols, P.D.; Malau-Aduli, A.E.O. Enhancement of dairy sheep cheese eating quality with increased n-3 long-chain polyunsaturated fatty acids. J. Dairy Sci. 2019, 102, 211-222. [CrossRef] [PubMed]

47. Benbrook, C.M.; Butler, G.; Latif, M.A.; Leifert, C.; Davis, D.R. Organic production enhances milk nutritional quality by shifting fatty acid composition: A United States-wide, 18-month study. PLoS ONE 2013, 8, e82429. [CrossRef] [PubMed]

48. Li, D.; Hu, X.J. Fish and its multiple human health effects in times of threat to sustainability and affordability: Are there alternatives? Asia Pac. J. Clin. Nutr. 2009, 18, 553-563. [PubMed]

49. Surette, M.E. The science behind dietary omega-3 fatty acids. CMAJ 2008, 178, 177-180. [CrossRef] [PubMed]

50. Calder, P.C. n-3 polyunsaturated fatty acids, inflammation, and inflammatory diseases. Am. J. Clin. Nutr. 2006, 83, 1505-1519. [CrossRef]

51. Kunnumakkara, A.B.; Sailo, B.L.; Banik, K.; Harsha, C.; Prasad, S.; Gupta, S.C.; Bharti, A.C.; Aggarwal, B.B. Chronic diseases, inflammation, and spices: How are they linked? J. Transl. Med. 2018, 16, 14. [CrossRef] [PubMed]

52. Surette, M.E.; Koumenis, L.L.; Edens, M.B.; Tramposch, K.M.; Chilton, F.H. Inhibition of leukotriene synthesis, pharmacokinetics, and tolerability of a novel dietary fatty acid formulation in healthy adult subjects. Clin. Ther. 2003, 25, 948-971. [CrossRef]

53. Zuijdgeest-Van Leeuwen, S.D.; Dagnelie, P.C.; Rietveld, T.; van den Berg, J.W.O.; Wilson, J.H.P. Incorporation and washout of orally administered n-3 fatty acid ethyl esters in different plasma lipid fractions. Br. J. Nutr. 1999, 82, 481-488. [CrossRef] [PubMed]

54. Alexander, D.D.; Miller, P.E.; Van Elswyk, M.E.; Kuratko, C.N.; Bylsma, L.C. A meta-analysis of randomized controlled trials and prospective cohort studies of eicosapentaenoic and docosahexaenoic long-chain omega-3 fatty acids and coronary heart disease risk. Mayo Clin. Proc. 2017, 92, 15-29. [CrossRef]

55. Bu, J.; Dou, Y.; Tian, X.; Wang, Z.; Chen, G. The role of omega-3 polyunsaturated fatty acids in stroke. Oxid. Med. Cell. Longev. 2016, 2016, 6906712. [CrossRef] [PubMed]

56. Mozaffarian, D.; Benjamin, E.J.; Go, A.S.; Arnett, D.K.; Blaha, M.J.; Cushman, M.; Das, S.R.; de Ferranti, S.; Despres, J.P.; Fullerton, H.J.; et al. Heart disease and stroke statistics-2016 update: A report from the American Heart Association. Circulation 2016, 133, e38-e360. [CrossRef] [PubMed]

57. Colussi, G.; Catena, C.; Novello, M.; Bertin, N.; Sechi, L.A. Impact of omega-3 polyunsaturated fatty acids on vascular function and blood pressure: Relevance for cardiovascular outcomes. Nutr. Metab. Cardiovasc. Dis. 2017, 27, 191-200. [CrossRef] [PubMed]

58. Frostegard, J. Immunity, atherosclerosis and cardiovascular disease. BMC Med. 2013, 11, 117. [CrossRef] [PubMed]

59. Jones, P.J.; Senanayake, V.K.; Pu, S.; Jenkins, D.J.; Connelly, P.W.; Lamarche, B.; Couture, P.; Charest, A.; Baril-Gravel, L.; West, S.G.; et al. DHA-enriched high-oleic acid canola oil improves lipid profile and lowers predicted cardiovascular disease risk in the canola oil multicenter randomized controlled trial. Am. J. Clin. Nutr. 2014, 100, 88-97. [CrossRef] [PubMed]

60. Shirley, R.; Ord, E.N.; Work, L.M. Oxidative stress and the use of antioxidants in stroke. Antioxidants 2014, 3, 472-501. [CrossRef] [PubMed] 
61. Zhao, W.; Tang, H.; Yang, X.D.; Luo, X.Q.; Wang, X.Y.; Shao, C.; He, J.Q. Fish consumption and stroke risk: A meta-Analysis of prospective cohort studies. J. Stroke Cerebrovasc. Dis. 2019, 28, 604-611. [CrossRef] [PubMed]

62. Shahidi, F.; Ambigaipalan, P. Omega-3 polyunsaturated fatty acids and their health benefits. Annu. Rev. Food Sci. Technol. 2018, 9, 345-381. [CrossRef] [PubMed]

63. Kato, I.; Akhmedkhanov, A.; Koenig, K.; Toniolo, P.G.; Shore, R.E.; Riboli, E. Prospective study of diet and female colorectal cancer: The New York University Women's Health Study. Nutr. Cancer 1997, 28, $276-281$. [CrossRef]

64. Terry, P.; Lichtenstein, P.; Feychting, M.; Ahlbom, A.; Wolk, A. Fatty fish consumption and risk of prostate cancer. Lancet 2001, 357, 1764-1766. [CrossRef]

65. Takezaki, T.; Inoue, M.; Kataoka, H.; Ikeda, S.; Yoshida, M.; Ohashi, Y.; Tajima, K.; Tominaga, S. Diet and lung cancer risk from a 14-year population-based prospective study in Japan: With special reference to fish consumption. Nutr. Cancer 2003, 45, 160-167. [CrossRef]

66. Van Blarigan, E.; Fuchs, C.S.; Niedzwiecki, D.; Ye, X.; Zhang, S.; Song, M.Y. Long-chain omega-3 fatty acid and fish intake after colon cancer diagnosis and disease-free, recurrence-free, and overall survival in CALGB 89803 (Alliance). J. Clin. Oncol. 2017, 35, 1227-1230. [CrossRef]

67. Makarem, N.; Chandran, U.; Bandera, E.V.; Parekh, N. Dietary Fat in Breast Cancer Survival. Annu. Rev. Nutr. 2013, 33, 319-348. [CrossRef] [PubMed]

68. Sczaniecka, A.K.; Brasky, T.M.; Lampe, J.W.; Patterson, R.E.; White, E. Dietary intake of specific fatty acids and breast cancer risk among postmenopausal women in the VITAL cohort. Nutr. Cancer 2012, 64, 1131-1142. [CrossRef] [PubMed]

69. Pereira, P.; Reis, A.D.; Diniz, R.R.; Lima, F.A.; Leite, R.D.; da Silva, M.C.P.; Guerra, R.N.M.; Vieira, E.B.D.; Garcia, J.B.S. Dietary supplements and fatigue in patients with breast cancer: A systematic review. Breast Cancer Res. Treat. 2018, 171, 515-526. [CrossRef] [PubMed]

70. Rizos, E.C.; Ntzani, E.E.; Bika, E.; Kostapanos, M.S.; Elisaf, M.S. Association between omega-3 fatty acid supplementation and risk of major cardiovascular disease events: A systematic review and meta-analysis. JAMA 2012, 308, 1024-1033. [CrossRef]

71. Rhee, J.J.; Kim, E.; Buring, J.E.; Kurth, T. Fish consumption, omega-3 fatty acids, and risk of cardiovascular disease. Am. J. Prev. Med. 2017, 52, 10-19. [CrossRef] [PubMed]

72. Holmes, M.D.; Colditz, G.A.; Hunter, D.J.; Hankinson, S.E.; Rosner, B.; Speizer, F.E.; Willett, W.C. Meat, fish and egg intake and risk of breast cancer. Int. J. Cancer 2003, 104, 221-227. [CrossRef] [PubMed]

73. Park, M.K.; Kyung, W.Q.; Li, T.; Qureshi, A.A.; Cho, E. Prospective Evaluation of Fat Intake and Risk of Skin Cancer. FASEB J. 2017, 31, 168-173.

74. Salem, N.; Litman, B.; Kim, H.Y.; Gawrisch, K. Mechanisms of action of docosahexaenoic acid in the nervous system. Lipids 2001, 36, 945-959. [CrossRef] [PubMed]

75. Dyall, S.C. Long-chain omega-3 fatty acids and the brain: A review of the independent and shared effects of EPA, DPA and DHA. Front. Aging Neurosci. 2015, 7, 52. [CrossRef] [PubMed]

76. Cole, G.M.; Ma, Q.L.; Frautschy, S.A. Omega-3 fatty acids and dementia. Prostaglandins Leukot. Essent. Fatty Acids 2009, 81, 213-221. [CrossRef]

77. Da Silva, T.M.; Munhoz, R.P.; Alvarez, C.; Naliwaiko, K.; Kiss, A.; Andreatini, R.; Ferraz, A.C. Depression in Parkinson's disease: A double-blind, randomized, placebo-controlled pilot study of omega-3 fatty-acid supplementation. J. Affect. Disord. 2008, 111, 351-359. [CrossRef]

78. Abdulrazaq, M.; Innes, J.K.; Calder, P.C. Effect of omega-3 polyunsaturated fatty acids on arthritic pain: A systematic review. Nutrition 2017, 39-40,57-66. [CrossRef]

79. Tsitouras, P.D.; Gucciardo, F.; Salbe, A.D.; Heward, C.; Harman, S.M. High omega-3 fat intake improves insulin sensitivity and reduces CRP and IL6, but does not affect other endocrine axes in healthy older adults. Horm. Metab. Res. 2008, 40, 199-205. [CrossRef]

80. Wang, L.; Folsom, A.R.; Zheng, Z.J.; Pankow, J.S.; Eckfeldt, J.H.; Investigators, A.S. Plasma fatty acid composition and incidence of diabetes in middle-aged adults: The atherosclerosis risk in communities (ARIC) study. Am. J. Clin. Nutr. 2003, 78, 91-98.

81. Wu, J.H.; Micha, R.; Imamura, F.; Pan, A.; Biggs, M.L.; Ajaz, O.; Djousse, L.; Hu, F.B.; Mozaffarian, D. Omega-3 fatty acids and incident type 2 diabetes: A systematic review and meta-analysis. Br. J. Nutr. 2012, 107, 214-227. [CrossRef] [PubMed] 
82. Albracht-Schulte, K.; Kalupahana, N.S.; Ramalingam, L.; Wang, S.; Rahman, S.M.; Robert-McComb, J.; Moustaid-Moussa, N. Omega-3 fatty acids in obesity and metabolic syndrome: A mechanistic update. J. Nutr. Biochem. 2018, 58, 1-16. [CrossRef] [PubMed]

83. He, K.; Rimm, E.B.; Merchant, A.; Rosner, B.A.; Stampfer, M.J.; Willett, W.C.; Ascherio, A. Fish consumption and risk of stroke in men. JAMA 2002, 288, 3130-3136. [CrossRef]

84. Iso, H.; Rexrode, K.M.; Stampfer, M.J.; Manson, J.E.; Colditz, G.A.; Speizer, F.E.; Hennekens, C.H.; Willett, W.C. Intake of fish and omega-3 fatty acids and risk of stroke in women. JAMA 2001, 285, 304-312. [CrossRef] [PubMed]

85. Thota, R.N.; Ferguson, J.J.A.; Abbott, K.A.; Dias, C.B.; Garg, M.L. Science behind the cardio-metabolic benefits of omega-3 polyunsaturated fatty acids: Biochemical effects vs. clinical outcomes. Food Funct. 2018, 9, 3576-3596. [CrossRef]

86. O'Connell, T.D.; Block, R.C.; Huang, S.P.; Shearer, G.C. w3-Polyunsaturated fatty acids for heart failure: Effects of dose on efficacy and novel signaling through free fatty acid receptor 4. J. Mol. Cell Cardiol. 2017, 103, 74-92. [CrossRef]

87. Chilliard, Y.; Glasser, F.; Ferlay, A.; Bernard, L.; Rouel, J.; Doreau, M. Diet, rumen biohydrogenation and nutritional quality of cow and goat milk fat. Eur. J. Lipid. Sci. Technol. 2007, 109, 828-855. [CrossRef]

88. Buccioni, A.; Decandia, M.; Minieri, S.; Molle, G.; Cabiddu, A. Lipid metabolism in the rumen: New insights on lipolysis and biohydrogenation with an emphasis on the role of endogenous plant factors. Anim. Feed Sci. Technol. 2012, 174, 1-25. [CrossRef]

89. Harfoot, C.G.; Hazlewood, G.P. Lipid metabolism in the rumen. In The Rumen Microbial Ecosystem; Hobson, P.N., Ed.; Elsevier Applied Science Publishers: London, UK, 1988; pp. 285-322.

90. Bauman, D.E.; Lock, A.L. Concepts in lipid digestion and metabolism in dairy cows. In Proceedings of the Tri-State Dairy Nutrition Conference, Fort Wayne, IN, USA, 25-26 April 2006; Eastridge, M.L., Ed.; pp. 1-14.

91. Shingfield, K.J.; Bernard, L.; Leroux, C.; Chilliard, Y. Role of trans fatty acids in the nutritional regulation of mammary lipogenesis in ruminants. Animal 2010, 4, 1140-1166. [CrossRef] [PubMed]

92. Shingfield, K.J.; Kairenius, P.; Arola, A.; Paillard, D.; Muetzel, S.; Ahvenjarvi, S.; Vanhatalo, A.; Huhtanen, P.; Toivonen, V.; Griinari, J.M.; et al. Dietary fish oil supplements modify ruminal biohydrogenation, alter the flow of fatty acids at the omasum, and induce changes in the ruminal Butyrivibrio population in lactating cows. J. Nutr. 2012, 142, 1437-1448. [CrossRef] [PubMed]

93. Kairenius, P.; Toivonen, V.; Shingfield, K.J. Identification and ruminal outflow of long-chain fatty acid biohydrogenation intermediates in cows fed diets containing fish oil. Lipids 2011, 46, 587-606. [CrossRef]

94. Chilliard, Y.; Ferlay, A.; Mansbridge, R.M.; Doreau, M. Ruminant milk fat plasticity: Nutritional control of saturated, polyunsaturated, trans and conjugated fatty acids. Ann. Zootech. 2000, 49, 181-205. [CrossRef]

95. Toral, P.G.; Hervas, G.; Leskinen, H.; Shingfield, K.J.; Frutos, P. In vitro ruminal biohydrogenation of eicosapentaenoic (EPA), docosapentaenoic (DPA), and docosahexaenoic acid (DHA) in cows and ewes: Intermediate metabolites and pathways. J. Dairy Sci. 2018, 101, 6109-6121. [CrossRef] [PubMed]

96. Manso, T.; Gallardo, B.; Guerra-Rivas, C. Modifying milk and meat fat quality through feed changes. Small Ruminant Res. 2016, 142, 31-37. [CrossRef]

97. Bisig, W.; Eberhard, P.; Collomb, M.; Rehberger, B. Influence of processing on the fatty acid composition and the content of conjugated linoleic acid in organic and conventional dairy products-A review. Lait 2007, 87, 1-19. [CrossRef]

98. Collomb, M.; Schmid, A.; Sieber, R.; Wechsler, D.; Ryhanen, E.L. Conjugated linoleic acids in milk fat: Variation and physiological effects. Int. Dairy J. 2006, 16, 1347-1361. [CrossRef]

99. Prandini, A.; Sigolo, S.; Piva, G. A comparative study of fatty acid composition and CLA concentration in commercial cheeses. J. Food Compos. Anal. 2011, 24, 55-61. [CrossRef]

100. Dewhurst, R.J.; Shingfield, K.J.; Lee, M.R.F.; Scollan, N.D. Increasing the concentrations of beneficial polyunsaturated fatty acids in milk produced by dairy cows in high-forage systems. Anim. Feed Sci. Technol. 2006, 131, 168-206. [CrossRef]

101. Woods, V.B.; Fearon, A.M. Dietary sources of unsaturated fatty acids for animals and their transfer into meat, milk and eggs: A review. Livest. Sci. 2009, 126, 1-20. [CrossRef]

102. Gilliland, T.J.; Barrett, P.D.; Mann, R.L.; Agnew, R.E.; Fearon, A.M. Canopy morphology and nutritional quality traits as potential grazing value indicators for Lolium perenne varieties. J. Agric. Sci. 2002, 139, $257-273$. [CrossRef] 
103. Elgersma, A.; Ellen, G.; van der Horst, H.; Muuse, B.G.; Boer, H.; Tamminga, S. Comparison of the fatty acid composition of fresh and ensiled perennial ryegrass (Lolium perenne L.), affected by cultivar and regrowth interval. Anim. Feed Sci. Technol. 2003, 108, 191-205. [CrossRef]

104. Gomez-Cortes, P.; Frutos, P.; Mantecon, A.R.; Juarez, M.; de la Fuente, M.A.; Hervas, G. Effect of supplementation of grazing dairy ewes with a cereal concentrate on animal performance and milk fatty acid profile. J. Dairy Sci. 2009, 92, 3964-3972. [CrossRef]

105. Leiber, F.; Kreuzer, M.; Nigg, D.; Wettstein, H.R.; Scheeder, M.R.L. A study on the causes for the elevated n-3 fatty acids in cows' milk of alpine origin. Lipids 2005, 40, 191-202. [CrossRef]

106. Mierlita, D. Fatty acid profile and health lipid indices in the raw milk of ewes grazing part-time and hemp seed supplementation of lactating ewes. S. Afr. J. Anim. Sci. 2016, 46, 237-246.

107. Mohammed, R.; Stanton, C.S.; Kennelly, J.J.; Kramer, J.K.; Mee, J.F.; Glimm, D.R.; O’Donovan, M.; Murphy, J.J. Grazing cows are more efficient than zero-grazed and grass silage-fed cows in milk rumenic acid production. J. Dairy Sci. 2009, 92, 3874-3893. [CrossRef] [PubMed]

108. Gomez-Cortes, P.; Tyburczy, C.; Brenna, J.T.; Juarez, M.; de la Fuente, M.A. Characterization of cis-9 trans-11 trans-15 C18:3 in milk fat by GC and covalent adduct chemical ionization tandem MS. J. Lipid Res. 2009, 50, 2412-2420. [CrossRef] [PubMed]

109. Addis, M.; Cabiddu, A.; Pinna, G.; Decandia, M.; Piredda, G.; Pirisi, A.; Molle, G. Milk and cheese fatty acid composition in sheep fed Mediterranean forages with reference to conjugated linoleic acid cis-9, trans-11. J. Dairy Sci. 2005, 88, 3443-3454. [CrossRef]

110. Bonanno, A.; Di Grigoli, A.; Mazza, F.; De Pasquale, C.; Giosue, C.; Vitale, F.; Alabiso, M. Effects of ewes grazing sulla or ryegrass pasture for different daily durations on forage intake, milk production and fatty acid composition of cheese. Animal 2016, 10, 2074-2082. [CrossRef] [PubMed]

111. Guzatti, G.C.; Duchini, P.G.; Gama, M.A.S.; Ribeiro, H.M.N. Red clover silage improves milk fatty acid composition in dairy ewes. Can. J. Anim. Sci. 2018, 98, 787-793. [CrossRef]

112. Cabiddu, A.; Molle, G.; Decandia, M.; Spada, S.; Fiori, M.; Piredda, G.; Addis, M. Responses to condensed tannins of flowering sulla (Hedysarum coronarium L.) grazed by dairy sheep Part 2: Effects on milk fatty acid profile. Livest. Sci. 2009, 123, 230-240. [CrossRef]

113. Lourenco, M.; Ramos-Morales, E.; Wallace, R.J. The role of microbes in rumen lipolysis and biohydrogenation and their manipulation. Animal 2010, 4, 1008-1023. [CrossRef]

114. Hristov, A.N.; Price, W.J.; Shafii, B. A meta-analysis examining the relationship among dietary factors, dry matter intake, and milk and milk protein yield in dairy cows. J. Dairy Sci. 2004, 87, 2184-2196. [CrossRef]

115. Kennelly, J.J.; Bell, J.A.; Keating, A.F.; Doepel, L. Nutrition as a tool to alter milk composition. Adv. Dairy Tech. 2005, 17, 255-275.

116. Dubois, V.; Breton, S.; Linder, M.; Fanni, J.; Parmentier, M. Fatty acid profiles of 80 vegetable oils with regard to their nutritional potential. Eur. J. Lipid Sci. Technol. 2007, 109, 710-732. [CrossRef]

117. Petit, H.V. Review: Feed intake, milk production and milk composition of dairy cows fed flaxseed. Can. J. Anim. Sci. 2010, 90, 115-127. [CrossRef]

118. Bernacchia, R.; Preti, R.; Vinci, G. Chemical composition and health benefits of flaxseed. Austin J. Nutr. Food Sci. 2014, 2, 1045-1053.

119. Coppa, M.; Ferlay, A.; Monsallier, F.; Verdier-Metz, I.; Pradel, P.; Didienne, R.; Farruggia, A.; Montel, M.C.; Martin, B. Milk fatty acid composition and cheese texture and appearance from cows fed hay or different grazing systems on upland pastures. J. Dairy Sci. 2011, 94, 1132-1145. [CrossRef]

120. Stergiadis, S.; Leifert, C.; Seal, C.J.; Eyre, M.D.; Steinshamn, H.; Butler, G. Improving the fatty acid profile of winter milk from housed cows with contrasting feeding regimes by oilseed supplementation. Food Chem. 2014, 164, 293-300. [CrossRef] [PubMed]

121. Liu, S.; Zhang, R.; Kang, R.; Meng, J.; Ao, C. Milk fatty acids profiles and milk production from dairy cows fed different forage quality diets. Anim. Nutr. 2016, 2, 329-333. [CrossRef]

122. Mierlita, D.; Pop, I.M.; Lup, F.; Simeanu, D.; Vicas, S.I.; Simeanu, C. The fatty acid composition and health lipid indices in sheep raw milk under a pasture-based dairy system. Revista de Chimie 2018, 69, 160-165.

123. Mohamed, B.; Sahnoun, A.; Bouderoua, K.; Homrani, A. Diet of ewes improve the fatty acid composition of milk. Adv. Biores. 2018, 9, 18-25. 
124. Khas, E.; Wang, J.Q.; Bu, D.P.; Wang, L.; Drackley, J.K.; Liu, Q.S.; Yang, G.; Wei, H.Y.; Zhou, L.Y. Short communication: Responses to increasing amounts of free alpha-linolenic acid infused into the duodenum of lactating dairy cows. J. Dairy Sci. 2010, 93, 1677-1684. [CrossRef] [PubMed]

125. Kitessa, S.M.; Gulati, S.K.; Ashes, J.R.; Fleck, E.; Scott, T.W.; Nichols, P.D. Utilisation of fish oil in ruminants-I. Fish oil metabolism in sheep. Anim. Feed Sci. Technol. 2001, 89, 189-199. [CrossRef]

126. Kitessa, S.M.; Gulati, S.K.; Simos, G.C.; Ashes, J.R.; Scott, T.W.; Fleck, E.; Wynn, P.C. Supplementation of grazing dairy cows with rumen-protected tuna oil enriches milk fat with n-3 fatty acids without affecting milk production or sensory characteristics. Br. J. Nutr. 2004, 91, 271-278. [CrossRef] [PubMed]

127. Kitessa, S.M.; Peake, D.; Bencini, R.; Williams, A.J. Fish oil metabolism in ruminants. Anim. Feed Sci. Technol. 2003, 108, 1-14. [CrossRef]

128. Papadopoulos, G.; Goulas, C.; Apostolaki, E.; Abril, R. Effects of dietary supplements of algae, containing polyunsaturated fatty acids, on milk yield and the composition of milk products in dairy ewes. J. Dairy Res. 2002, 69, 357-365. [CrossRef]

129. Boeckaert, C.; Vlaeminck, B.; Dijkstra, J.; Issa-Zacharia, A.; Van Nespen, T.; Van Straalen, W.; Fievez, V. Effect of dietary starch or micro algae supplementation on rumen fermentation and milk fatty acid composition of dairy cows. J. Dairy Sci. 2008, 91, 4714-4727. [CrossRef] [PubMed]

130. Park, Y.W.; Juarez, M.; Ramos, M.; Haenlein, G.F.W. Physico-chemical characteristics of goat and sheep milk. Small Ruminant Res. 2007, 68, 88-113. [CrossRef]

131. Flakemore, A.R.; Malau-Aduli, B.S.; Nichols, P.D.; Malau-Aduli, A.E.O. Omega-3 fatty acids, nutrient retention values, and sensory meat eating quality in cooked and raw Australian lamb. Meat Sci. 2017, 123, 79-87. [CrossRef]

132. FSANZ (Food Standards Australia New Zealand). Standard 1.2.8: Nutrition Information Requirements; Australia New Zealand Food Standards Code; FSANZ: Canberra, Australia, 2002; Volume 2.

133. Watkins, P.J.; Frank, D.; Singh, T.K.; Young, O.A.; Warner, R.D. Sheep meat flavor and the effect of different feeding systems: A review. J. Agric. Food Chem. 2013, 61, 3561-3579. [CrossRef] [PubMed]

134. Caroprese, M.; Marzano, A.; Marino, R.; Gliatta, G.; Muscio, A.; Sevi, A. Flaxseed supplementation improves fatty acid profile of cow milk. J. Dairy Sci. 2010, 93, 2580-2588. [CrossRef]

135. Dai, X.J.; Wang, C.; Zhu, Q. Milk performance of dairy cows supplemented with rapeseed oil, peanut oil and sunflower seed oil. Czech J. Anim. Sci. 2011, 56, 181-191. [CrossRef]

136. Otto, J.R.; Malau-Aduli, B.S.; Nichols, P.D.; Malau-Aduli, A.E.O. Influence of supplementing pasture-based primiparous Holstein-Friesian dairy cows with crude degummed canola oil on milk fatty acid composition. J. Nutr. Ther. 2014, 3, 55-66.

137. Cattani, M.; Mantovani, R.; Schiavon, S.; Bittante, G.; Bailoni, L. Recovery of n-3 polyunsaturated fatty acids and conjugated linoleic acids in ripened cheese obtained from milk of cows fed different levels of extruded flaxseed. J. Dairy Sci. 2014, 97, 123-135. [CrossRef]

138. Li, R.; Beaudoin, F.; Ammah, A.A.; Bissonnette, N.; Benchaar, C.; Zhao, X.; Lei, C.Z.; Ibeagha-Awemu, E.M. Deep sequencing shows microRNA involvement in bovine mammary gland adaptation to diets supplemented with linseed oil or safflower oil. BMC Genom. 2015, 16, 884. [CrossRef] [PubMed]

139. Welter, K.C.; Martins, C.M.; de Palma, A.S.; Martins, M.M.; Dos Reis, B.R.; Schmidt, B.L.; Saran Netto, A. Canola oil in lactating dairy cow diets reduces milk saturated fatty acids and improves its omega-3 and oleic fatty acid content. PLoS ONE 2016, 11, e0151876. [CrossRef]

140. Vanbergue, E.; Peyraud, J.L.; Hurtaud, C. Effects of new n-3 fatty acid sources on milk fatty acid profile and milk fat properties in dairy cows. J. Dairy Res. 2018, 85, 265-272. [CrossRef] [PubMed]

141. Bodas, R.; Manso, T.; Mantecon, A.R.; Juarez, M.; De la Fuente, M.A.; Gomez-Cortes, P. Comparison of the fatty acid profiles in cheeses from ewes fed diets supplemented with different plant oils. J. Agric. Food Chem. 2010, 58, 10493-10502. [CrossRef]

142. Mughetti, L.; Sinesio, F.; Acuti, G.; Antonini, C.; Moneta, E.; Peparaio, M.; Trabalza-Marinucci, M. Integration of extruded linseed into dairy sheep diets: Effects on milk composition and quality and sensorial properties of Pecorino cheese. Anim. Feed Sci. Technol. 2012, 178, 27-39. [CrossRef]

143. Caroprese, M.; Ciliberti, M.G.; Marino, R.; Santillo, A.; Sevi, A.; Albenzio, M. Polyunsaturated fatty acid supplementation: Effects of seaweed ascophyllum nodosum and flaxseed on milk production and fatty acid profile of lactating ewes during summer. J. Dairy Res. 2016, 83, 289-297. [CrossRef] [PubMed] 
144. Parentet, M.D.M.; Susin, I.; Nolli, C.P.; Ferreira, E.M.; Gentil, R.S.; Polizel, D.M.; Pires, A.V.; Alves, S.P.; Bessa, R.J.B. Effects of supplementation with vegetable oils, including castor oil, on milk production of ewes and on growth of their lambs. J. Anim. Sci. 2018, 96, 354-363. [CrossRef] [PubMed]

145. Bianchi, A.E.; Da Silva, A.S.; Biazus, A.H.; Richards, N.; Pellegrini, L.G.; Baldissera, M.D.; Macedo, V.P.; Da Silveira, A.L.F. Adding palm oil to the diet of sheep alters fatty acids profile on yogurt: Benefits to consumers. Anais da Academia Brasileira de Ciencias 2017, 89, 2471-2478. [CrossRef]

146. Soyeurt, H.; Gillon, A.; Vanderick, S.; Mayeres, P.; Bertozzi, C.; Gengler, N. Estimation of heritability and genetic correlations for the major fatty acids in bovine milk. J. Dairy Sci. 2007, 90, 4435-4442. [CrossRef]

147. Stoop, W.M.; van Arendonk, J.A.; Heck, J.M.; van Valenberg, H.J.; Bovenhuis, H. Genetic parameters for major milk fatty acids and milk production traits of Dutch Holstein-Friesians. J. Dairy Sci. 2008, 91, 385-394. [CrossRef]

148. Bilal, G.; Cue, R.I.; Mustafa, A.F.; Hayes, J.F. Short communication: Genetic parameters of individual fatty acids in milk of Canadian Holsteins. J. Dairy Sci. 2014, 97, 1150-1156. [CrossRef] [PubMed]

149. Pegolo, S.; Cecchinato, A.; Casellas, J.; Conte, G.; Mele, M.; Schiavon, S.; Bittante, G. Genetic and environmental relationships of detailed milk fatty acids profile determined by gas chromatography in Brown Swiss cows. J. Dairy Sci. 2016, 99, 1315-1330. [CrossRef]

150. Correddu, F.; Cellesi, M.; Serdino, J.; Manca, M.G.; Contu, M.; Dimauro, C.; Ibba, I.; Macciotta, N.P.P. Genetic parameters of milk fatty acid profile in sheep: Comparison between gas chromatographic measurements and Fourier-transform IR spectroscopy predictions. Animal 2018, 13, 469-476. [CrossRef] [PubMed]

151. Boichard, D.; Govignon-gion, A.; Larroque, H.; Maroteau, C.; Palhière, I.; Tosser-Klopp, G.; Rupp, R.; Sanchez, M.-P.; Brochard, M. Déterminisme génétique de la composition en acides gras et protéines du lait des ruminants, et potentialités de sélection. INRA Prod. Anim. 2014, 27, 283-289.

152. Maroteau, C.; Palhiere, I.; Larroque, H.; Clement, V.; Ferrand, M.; Tosser-Klopp, G.; Rupp, R. Genetic parameter estimation for major milk fatty acids in Alpine and Saanen primiparous goats. J. Dairy Sci. 2014, 97, 3142-3155. [CrossRef]

153. Marquardt, A.; Stohr, H.; White, K.; Weber, B.H.F. cDNA cloning, genomic structure, and chromosomal localization of three members of the human fatty acid desaturase family. Genomics 2000, 66, 175-183. [CrossRef] [PubMed]

154. Malau-Aduli, A.E.O.; Bignell, C.W.; McCulloch, R.; Kijas, J.W.; Nichols, P.D. Genetic association of delta-six fatty acid desaturase (FADS) single nucleotide polymorphic molecular marker and muscle long chain omega-3 fatty acids in Australian lamb. In Global Challenges to Production, Processing and Consumption of Meat, Proceedings of the 57th International Congress of Meat Science and Technology, Ghent, Belgium, 7-12 August 2011; De Smet, S., Ed.; University of Ghent: Ghent, Belgium, 2011; Volume 57, p. 126.

155. Malau-Aduli, A.E.O.; Otto, J.R.; Suybeng, B.; Kashani, A.; Lane, P.A.; Malau-Aduli, B.S.; Nichols, P.D. Gene expression profiles of Aralkylamine N-acetyltransferase, B-cell translocation gene-2 and Fatty Acid Synthase genes in pasture-based primiparous Holstein-Friesian dairy cows supplemented with crude degummed canola oil. Adv. Genet. Eng. 2015, 4, 1000123. [CrossRef]

156. Malau-Aduli, A.E.O.; Kashani, A. Molecular genetics-nutrition interactions in the expression of AANAT, ADRB3, BTG2 and FASN genes in the heart, kidney and liver of Australian lambs supplemented with Spirulina (Arthrospira platensis). Genes Genom. 2015, 37, 633-644. [CrossRef]

157. Malau-Aduli, A.E.O.; Holman, B.W.B.; Kashani, A.; Nichols, P.D. Sire breed and sex effects on the fatty acid composition and content of heart, kidney, liver, adipose and muscle tissues of purebred and first-cross prime lambs. Anim. Prod. Sci. 2016, 56, 2122-2132. [CrossRef]

158. Malau-Aduli, A.E.O.; Nguyen, D.V.; Le, V.H.; Nguyen, Q.V.; Otto, J.R.; Malau-Aduli, B.S.; Nichols, P.D. Correlations between growth and wool quality traits of genetically divergent Australian lambs in response to canola or flaxseed oil supplementation. PLoS ONE 2019, 14, e0208229. [CrossRef]

159. Ibeagha-Awemu, E.M.; Akwanji, K.A.; Beaudoin, F.; Zhao, X. Associations between variants of FADS genes and omega-3 and omega-6 milk fatty acids of Canadian Holstein cows. BMC Genet. 2014, 15, 25. [CrossRef]

160. Ibeagha-Awemu, E.M.; Peters, S.O.; Akwanji, K.A.; Imumorin, I.G.; Zhao, X. High density genome wide genotyping-by-sequencing and association identifies common and low frequency SNPs, and novel candidate genes influencing cow milk traits. Sci. Rep. 2016, 6, 31109. [CrossRef] 
161. Franklin, S.T.; Martin, K.R.; Baer, R.J.; Schingoethe, D.J.; Hippen, A.R. Dietary marine algae (Schizochytrium sp.) increases concentrations of conjugated linoleic, docosahexaenoic and trans vaccenic acids in milk of dairy cows. J. Nutr. 1999, 129, 2048-2054. [CrossRef] [PubMed]

162. Shingfield, K.J.; Reynolds, C.K.; Hervas, G.; Griinari, J.M.; Grandison, A.S.; Beever, D.E. Examination of the persistency of milk fatty acid composition responses to fish oil and sunflower oil in the diet of dairy cows. J. Dairy Sci. 2006, 89, 714-732. [CrossRef]

163. Kazama, R.; Cortes, C.; da Silva-Kazama, D.; Gagnon, N.; Benchaar, C.; Zeoula, L.M.; Santos, G.T.D.; Petit, H.V. Abomasal or ruminal administration of flax oil and hulls on milk production, digestibility, and milk fatty acid profile of dairy cows. J. Dairy Sci. 2010, 93, 4781-4790. [CrossRef] [PubMed]

164. Vargas-Bello-Pérez, E.; Íñiguez-González, G.; Fehrmann-Cartes, K.; Toro-Mujica, P.; Garnsworthy, P.C. Influence of fish oil alone or in combination with hydrogenated palm oil on sensory characteristics and fatty acid composition of bovine cheese. Anim. Feed Sci. Technol. 2015, 205, 60-68. [CrossRef]

165. Kairenius, P.; Arola, A.; Leskinen, H.; Toivonen, V.; Ahvenjarvi, S.; Vanhatalo, A.; Huhtanen, P.; Hurme, T.; Griinari, J.M.; Shingfield, K.J. Dietary fish oil supplements depress milk fat yield and alter milk fatty acid composition in lactating cows fed grass silage-based diets. J. Dairy Sci. 2015, 98, 5653-5671. [CrossRef] [PubMed]

166. Toral, P.G.; Hervas, G.; Gomez-Cortes, P.; Frutos, P.; Juarez, M.; de la Fuente, M.A. Milk fatty acid profile and dairy sheep performance in response to diet supplementation with sunflower oil plus incremental levels of marine algae. J. Dairy Sci. 2010, 93, 1655-1667. [CrossRef] [PubMed]

167. Bichi, E.; Hervas, G.; Toral, P.G.; Loor, J.J.; Frutos, P. Milk fat depression induced by dietary marine algae in dairy ewes: Persistency of milk fatty acid composition and animal performance responses. J. Dairy Sci. 2013, 96, 524-532. [CrossRef] [PubMed]

(C) 2019 by the authors. Licensee MDPI, Basel, Switzerland. This article is an open access article distributed under the terms and conditions of the Creative Commons Attribution (CC BY) license (http://creativecommons.org/licenses/by/4.0/). 